\title{
RESEARCH
}

Open Access

\section{The impacts of land-use and land-cover change on wetland ecosystem service values in peri-urban and urban area of Bahir Dar City, Upper Blue Nile Basin, Northwestern Ethiopia}

\author{
Workiyie Worie Assefa ${ }^{1 *}$ (D) Belachew Getnet Eneyew ${ }^{2}$ and Ayalew Wondie ${ }^{3}$
}

\begin{abstract}
Background: Even though wetlands are essential in enhancing water quality and providing recreation and entertainment opportunities in urban areas, their values are overlooked by the decision-makers. Underestimation of the economic value of wetland ecosystem services contributes to their continuing deterioration and inevitable loss. Investigating the changes in ecosystem service values (ESV) can provide crucial information for decision-making. This study, therefore, analyzes the temporal and spatial land-use/land-cover (LULC) change patterns over 35 years (1984-2019) intending to evaluate its impact on wetland ecosystem service values in Bahir Dar City, Ethiopia. Estimation and change analyses of ESVs were conducted by employing ArcGIS using LULC inputs of the year 1984, 1994, 2004, 2014, and 2019 with their corresponding global value coefficients that were developed earlier and our own modified value coefficients for the studied landscape.

Results: The results showed that wetlands and water bodies of the city and its peripheries had decreased by 75.71\% (-1618 ha) within 35 years, while built-up area increased by $216.24 \%$ (+2599 ha). Cultivated land had increased slightly from 1984 to 1994 and then gradually declined since 1994. Changes in LULC had resulted in a decline of the total ESV. The total ESV had decreased from USD $29.73 \times 10^{6}$ to USD $20.84 \times 10^{6}$ in 35 years. This indicates the loss of nearly USD $8.9 \times 10^{6}$ ESV from 1984 to 2019. A sensitivity analysis suggested the robustness of ESV estimation in the study area. All individual ecosystem services experienced a negative change. However, a greater reduction in ESV was observed for services such as water regulation, waste treatment, and habitats for maintaining biodiversity. The expansion of built-up area of Bahir Dar City was the major factor that contributed to the loss of ESV provided by wetlands.
\end{abstract}

Conclusions: The loss of ESV resulting in LULC changes has a negative implication on local climate, waste management, and the livelihoods of the poor community. Thus, interventions should be made for the restoration and sustainable management of wetlands in the urban and peri-urban areas of Bahir Dar City.

Keywords: Ecosystem service, Economic valuation, Land use/land cover, Landscape change, Urban wetland

\footnotetext{
* Correspondence: Workiye2008@gmail.com

'Department of Biology, College of Science, Blue Nile Water Institute, Bahir

Dar University, P.O. Box 79, Bahir Dar, Ethiopia

Full list of author information is available at the end of the article
}

\section{Springer Open}

(-) The Author(s). 2021 Open Access This article is licensed under a Creative Commons Attribution 4.0 International License, which permits use, sharing, adaptation, distribution and reproduction in any medium or format, as long as you give appropriate credit to the original author(s) and the source, provide a link to the Creative Commons licence, and indicate if changes were made. The images or other third party material in this article are included in the article's Creative Commons licence, unless indicated otherwise in a credit line to the material. If material is not included in the article's Creative Commons licence and your intended use is not permitted by statutory regulation or exceeds the permitted use, you will need to obtain permission directly from the copyright holder. To view a copy of this licence, visit http://creativecommons.org/licenses/by/4.0/. 


\section{Introduction}

Wetlands are highly biodiverse and the most valuable ecosystems on our planet (Mitsch and Gosselink 2000, 2015). They deliver a wide range of direct and indirect benefits both locally and globally (Costanza et al. 2014, 1997; de Groot et al. 2012; MEA (Millennium Ecosystem Assessment) 2005; Russi et al. 2013; Van der Ploeg et al. 2010). These include supporting (e.g., nutrient recycling, soil formation, biodiversity support), regulating (e.g., hydrological flows, erosion regulation), provisioning (e.g., fish and fiber, genetic materials), and cultural services (e.g., tourism, source of inspiration) (MEA (Millennium Ecosystem Assessment) 2005). The most significant ecological services provided by urban wetlands are water supply, waste treatment, local climate regulation, and flood control (MEA (Millennium Ecosystem Assessment) 2005; Huang et al. 2019). Despite providing vital services, wetlands are declining at alarming rates faster than any other ecosystems (MEA (Millennium Ecosystem Assessment) 2005). Half of the world's wetlands have been lost since the beginning of the twentieth century (Davidson 2014) and more than 60\% of the remaining wetland ecosystems were being degraded or used unsustainably (MEA (Millennium Ecosystem Assessment) 2005). The loss of wetlands in Ethiopia is also considerable (Teferi et al. 2010; Shewit et al. 2017). Urban encroachment, agricultural expansion, sedimentation, and excessive water extraction for agriculture are accountable for substantial loss of wetlands in Ethiopia (Ethiopian Wildlife and Natural History Society (EWNHS) 2018; Wondie 2018; Assefa et al. 2020). Changes in LULC have in turn resulted in changes in the economic and ecological values of various ecosystem services (Leh et al. 2013; Wang et al. 2017; Sadat et al. 2019; Sun et al. 2018; Sun et al. 2019; Hasan et al. 2020).

Estimating ESV and its changes over time is fundamental in providing valuable information about the impact of LULC dynamics on ecosystem services (Costanza et al. 1997; Anaya-Romero et al. 2016; Ferreira et al. 2019). It will also be a guidance for a comprehensive evaluation of the trade-offs among alternative land uses (de Groot et al. 2012; Yi et al. 2017). Cognizant of this fact, several studies valued the loss of ecosystem services in relation to land-use changes (Liu et al. 2012; Zhang et al. 2015; Kindu et al. 2016; Balthazar et al. 2015; Tolessa et al. 2017; Zhao et al. 2017; Gashaw et al. 2018; Paudyal et al. 2019). Some of these studies estimated the impact of LULC on forest ecosystem service values (Balthazar et al. 2015; Kindu et al. 2016; Tolessa et al. 2017). Some others (Song et al. 2015; Arowolo et al. 2018; Gashaw et al. 2018) estimated the loss of different terrestrial ecosystem services caused by LULC dynamics. The effect of LULC on ecosystem services provided by wetlands was also documented (Zhao et al. 2004; Zorrilla-Miras et al. 2014; Gaglio et al. 2016; Badamfirooz and Mousazadeh 2019; Huang et al. 2019; Rojas et al. 2019; Liu et al. 2020). The findings of some of these studies revealed the negative effect of LULC change on ecosystem services (Zhang et al. 2015; Yirsaw et al. 2017; Aneseyee et al. 2019; Liu et al. 2020). The reports of few others (e.g., Badamfirooz and Mousazadeh 2019) showed the gains of ecosystem service values due to LULC. Even though these studies provide information on how the LULC affected the ecosystem service values, most of them were conducted in specific regions (South East and East Asian). The economic losses or gains of ecosystem services associated with LULC in Africa including Ethiopia are not adequately estimated. Only a few studies (Kindu et al. 2016; Tolessa et al. 2017; Gashaw et al. 2018; Aneseyee et al. 2019) estimated the effect of LULC on ecosystem services. The scopes of these studies, however, were micro-watershed in rural landscape or forest ecosystem. The impact of LULC as a result of urban expansion on ecosystem services is not adequately addressed.

In Ethiopia, urban areas have been highly expanded for the last two or more decades (Terfa et al. 2019). The rapid urban expansion poses enormous effects on ecosystem services. It alters wetland hydrology and water quality (Ehrenfeld 2000; Kentula et al. 2004; Ethiopian Wildlife and Natural History Society (EWNHS) 2018) and connectivity (Heintzman and McIntyre 2019), which in turn results in biodiversity loss (Yi et al. 2018). Previously, few studies have been done in relation to Bahir Dar City expansion and its impacts on LULC. Admasu et al. (2020) conducted a study on the ecosystem services of expropriated land in Bahir Dar City. This study was mainly focused on the ecosystem services of three landuse types such as cropland, agroforestry, and grassland that are threatened by Bahir Dar City expansion. Besides, they evaluated the ecosystem services of expropriated land use types using community perception and expert judgments only. The wetland ecosystem services that are threatened by city expansion were not addressed and the values of ecosystem services were not quantified. Two other studies (Haregeweyn et al. 2012; Fitawok et al. 2020) were also conducted on the LULC of Bahir Dar City and the underlining factors for its LULC dynamics. But, the impact of LULC on ecosystem services and ecosystem services values lost or gained by LULC were not the focus of these studies. Moreover, in their LULC classification, they did not treat wetlands separately; rather they mixed wetlands with other land cover classes such as forests, rangelands, and water. Giving scant attention to wetland ecosystem services that are 
provided to urban areas by research and development projects contributes to their underestimation. McInnes (2013) argues that creating the awareness of users, planners, and decision-makers on the benefits of wetlands is the cornerstone for their sustainable utilization and management in urban and peri-urban environments. Valuation of wetland ecosystem services can be helpful to raise the awareness of decision-makers (Costanza et al. 1997).

This study thus aimed to analyze the impacts of spatialtemporal land-use change of Bahir Dar City from 1984 to 2019 on wetland ecosystem services through a monetary valuation approach. The results of this study will contribute to the overall environmental management, spatial planning, and policy-making for the protection and sustainable management of wetlands and water bodies in the study area.

\section{Materials and methods}

\section{Study area description}

Bahir Dar is the capital city of Amhara National Regional State. It is located in the northwestern highlands of Ethiopia at $37^{\circ} 10^{\prime}$ E longitude and $11^{\circ} 38^{\prime}$ $\mathrm{N}$ latitude and its average altitude is $1830 \mathrm{~m}$ above sea level (Fig. 1). Topographically, the city lies on a flat surface with almost no slope gradient except for small increases in elevation in the eastern and western peripheries. Based on the simplified traditional agro-climatic classification system, Bahir Dar falls within the Woina-Dega climatic condition. The mean annual atmospheric temperature of the city ranges from 15 to $21^{\circ} \mathrm{C}$ and its average annual rainfall was $1445 \mathrm{~mm}$, of which about 84-90\% occurs from June to September (Addisu et al. 2015).

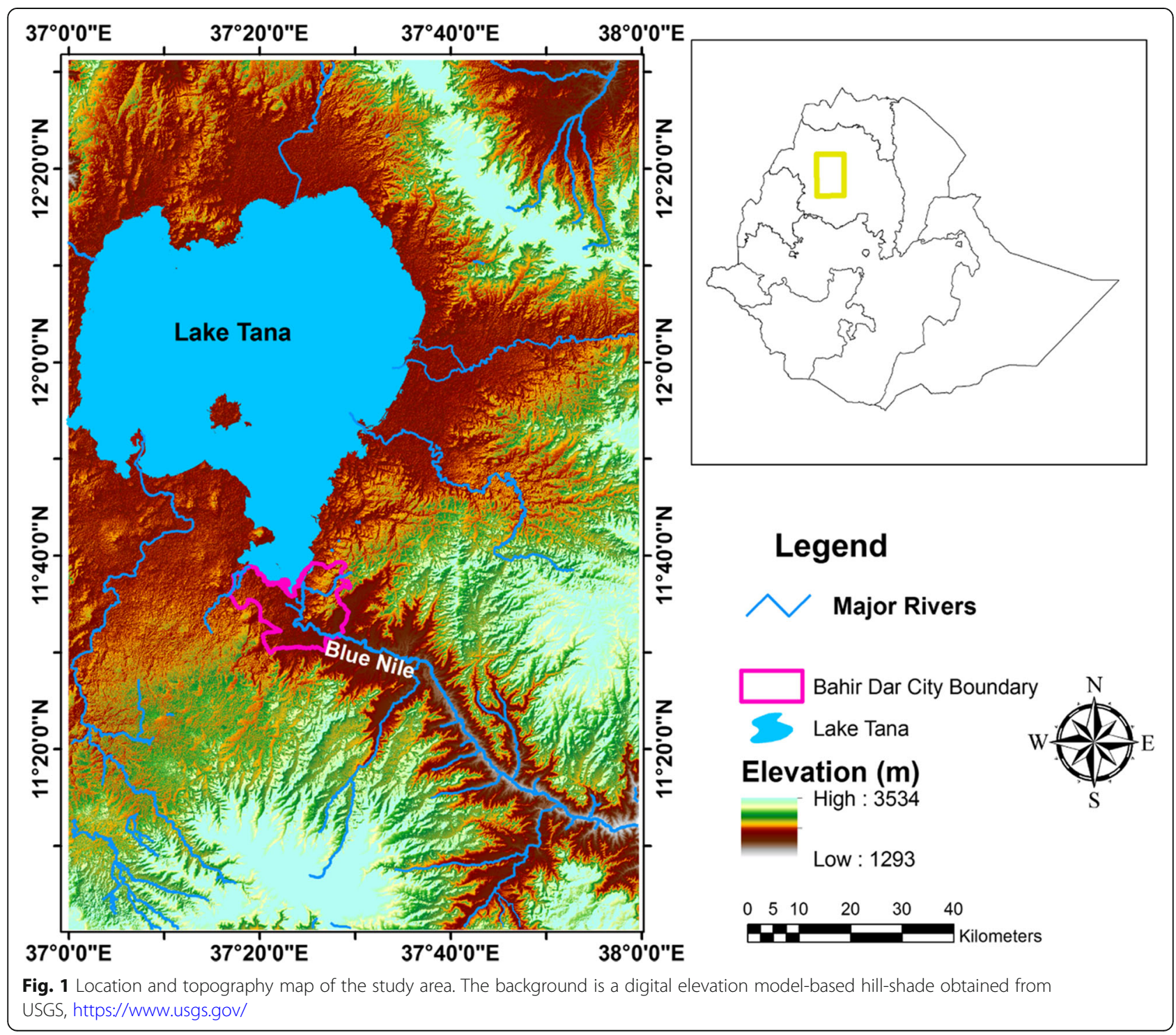


The historical foundation of Bahir Dar City is associated with the establishment of Saint Kidane Miheret Church in the present site of St. Giorgis Church around the fourteenth century (Seyoum 1988). However, it was a small village until the Italian occupation (Seyoum 1988). The village was transformed into a modern township during the Italian occupation (1928-1933). During this period, the town was used as a major military base for expeditions in the region. Immediately after the Italian evacuation, Bahir Dar was selected as the Awuraja capital in 1948. The town went through a rapid transformation in the 1960s and 1970s and became the capital of the West Gojjam Province in 1987. In 1993, it was selected as an administrative seat of Amhara National Regional State, and consequently, it has been rapidly expanded into four rural kebele administrations adjacent to the main urban center (Adam 2014). Based on CSA projection, the total population of Bahir Dar City in 2017 was estimated to be over 396,000 (CSA 2007). Currently, the city is the political and economic center of Amhara National Regional State. Besides, it is one of the major tourist centers in the country because of its cultural heritage such as the Lake Tana Monasteries and natural attractions such as the Blue Nile Falls, birds, and hippos. Since the city is situated on Lake Tana shore and riverbank of Abbay, there are lacustrine and riverine wetlands in the city and its peri-urban kebele administrations (Wondie 2018).

\section{Data collection, image processing, and classification}

Time series data of LULC of the study area were analyzed using Landsat imagery (TM, ETM+, OLIS/TIRS) obtained from the United States Geological Survey (USGS, https://www.usgs.gov/). All the images were cloud-free and acquired in 1984, 1994, 2004, 2014, and 2019 (Table 1). They were level 1 products that were already geographically projected to UTM zone 37N WGS84. Their acquisition times were the dry season (between December and March) for each study year to make sure that the vegetation and hydrology of the study area were in similar conditions. The images, then, were converted to top-of-atmosphere (TOA) reflectance values based on Chander et al. (2009) algorithm. Dark Object Subtraction (DOS) approaches were applied to all Landsat data for atmospheric correction (Chavez 1996; Zhang et al. 2010) using the Semi-Automatic Classification Plugin of QGIS 3.8. The strips in the 2004 image were also removed using Scan Line Corrector (SLC). The images were composited and extracted using the study area boundary shapefile in ArcGIS 10.4. The years in which population and housing census took place in Ethiopia and availability of quality satellite images are used as reference study periods.

After image enhancements (standard false-color composition and standard deviation stretch), sufficient training polygons were collected to identify LULC categories using the training sample manager in ArcGIS 10.4 (Lillesand et al. 2015). Based on these data, the five images were classified into six land-use categories (built-up area, cultivated, vegetation, grazing land, wetland and water body) using the Random Forest image classification algorithm (Table 2). Random Forest was proposed by Breiman (2001) and has been increasingly used by professionals. This is because it is more robust than the traditional image classification algorithms and provides high classification accuracy for using unbalanced and small training data sets (Jin et al. 2018).

The extent of individual LULC change over time was evaluated using percent change (PC; Eq. 1) (Fenta et al. 2017; Berihun et al. 2019) and transition matrix model (Gashaw et al. 2017; Berihun et al. 2019).

$$
P C=\frac{U b-U a}{U a} \times 100 \%
$$

where $\mathrm{PC}=\mathrm{LULC}$ rate of changes, $\mathrm{Ua}=$ area of start date LULC type, and Ub= area of end-date LULC type.

A land-use transition matrix was used to illustrate the direction and area of different LULC types change within a given time. This was performed between different periods using cross-tabulation and overlayintersection in ArcGIS 10.4 software. The attribute tables obtained from these analyses were exported to Microsoft Excel to compute area change and rate of change of different years.

The accuracy of the output map was verified by performing classification accuracy assessment (Kappa coefficient and overall accuracy) using field GPS data, aerial photos, group discussion, key informant interviews, and

Table 1 Description of satellite image data that are used for the land use/land cover study of Bahir Dar City

\begin{tabular}{llllll}
\hline Year & Satellite sensor & Date acquired & Spatial resolution & Path/Row & Bands used \\
\hline 1984 & Landsat 5 TM & $31 / 12 / 1984$ & $30 \mathrm{~m} \times 30 \mathrm{~m}$ & $170 / 52$ & $1,2,3,4,5 \& 7$ \\
1994 & Landsat 5 TM & $25 / 01 / 1994$ & $30 \mathrm{~m} \times 30 \mathrm{~m}$ & $170 / 52$ & $1,2,3,4,5 \& 7$ \\
2004 & Landsat 7 ETM+ & $26 / 01 / 2004$ & $30 \mathrm{~m} \times 30 \mathrm{~m}$ & $170 / 52$ & $1,2,3,4,5 \& 7$ \\
2014 & Landsat 8 OLIS/TIRS & $12 / 02 / 2014$ & $30 \mathrm{~m} \times 30 \mathrm{~m}$ & $170 / 52$ & $1,2,3,4,5 \& 7$ \\
2019 & Landsat 8 OLIS/TIRS & $28 / 03 / 2019$ & $30 \mathrm{~m} \times 30 \mathrm{~m}$ & $170 / 52$ & $2,3,4,5,6 \& 7$ \\
\hline
\end{tabular}


Table 2 The land use/land cover (LULC) categories of Bahir Dar City and their descriptions

\begin{tabular}{|c|c|}
\hline $\begin{array}{l}\text { LULC } \\
\text { categories }\end{array}$ & Descriptions \\
\hline Cultivated land & Areas covered with annual crops, vegetables, fruits, Khat plantations, including irrigated land \\
\hline Grazing land & Land covered primarily with grasses having scattered trees serving as pasture and grazing cattle \\
\hline Vegetation & $\begin{array}{l}\text { Land covered with relatively dense forest, open forest, shrubs, church forests, trees scatted in the city, riverine forests and Eucalyptus } \\
\text { plantations }\end{array}$ \\
\hline Water body & Refers to river and stream courses, lakes, ponds and open water in the wetland. Irrigation canals also included \\
\hline Built-up area & $\begin{array}{l}\text { Areas covered with buildings constructed for residential, commercial and industrial purposes, and transport facilities such as roads } \\
\text { and airport. Sport fields and stadiums are also part of this category. }\end{array}$ \\
\hline Wetland & $\begin{array}{l}\text { Areas consisted of papyrus and phragmites swamps along with the river banks and the lakeshore areas. Swampy areas, meadows, } \\
\text { either or seasonal or permanent waterlogged, supporting hydrophytic plants degraded with human activities considered as } \\
\text { wetlands }\end{array}$ \\
\hline
\end{tabular}

reference images (Congalton 1991). Data from field surveys, interviews, and Google earth were used to train and validate the image in 2019. About 50 to 60 ground truth points were collected in the field and Google Earth-Pro images for each LULC category (Lillesand et al. 2015). However, the sample size of wetlands was 60 points to increase its separability from vegetation and agriculture as they show similar spectral signatures. An accuracy assessment confirmed the resulting LULC maps fulfilled the required standards (overall classification accuracy ranged from 86.3 to $93.4 \%$ with Kappa coefficient of 0.83-0.91) to do a further ESV estimation on different LULC categories (Monserud and Leemans 1992).

\section{Estimation of ecosystem service values (ESV)}

There are several approaches for the estimation of ecosystem service values, including the direct market-based valuation approach (market price approach, cost-based approach and production function approach), revealed preference approach (travel cost method and hedonic pricing), and stated preference approach (such as contingent valuation method and choice modeling (Adamowicz et al. 2008). In this study, the Kindu et al. (2016) equivalent coefficient of ESV for the terrestrial environment was adopted for the analysis of ESV. Considering Ethiopian local conditions, Kindu et al. (2016) developed
ESV for 11 biomes based on Costanza et al. (1997) approach. Of these, we select only five LULC categories that are appropriate proxy for our LULC types: (1) cropland for cultivated land, (2) tropical forest for vegetation, (3) grassland for grazing land, (4) urban for the built-up area, and (5) water body for water body (Tables 3 and 4). The tropical forest biome was not a perfect proxy for vegetation types in the study area because the vegetation in our study area includes open forests, dense forests, riverine forests, church forests, and eucalyptus plantations (Table 2). However, by assuming the similarity of the services provided by tropical forest and the vegetation of our study area, we have taken the biome as the closest proxy. On the other hand, the value coefficient of built-up area is assigned to zero value following Kindu et al. (2016) value coefficients that was modified based on Costanza et al. (1997) because Costanza et al. (1997) did not recognize ecosystem services such as carbon sequestration in urban areas. Change in ESV of the study area were calculated using the LULC data classified for the years 1984, 1994, 2004, 2014, and 2019 based on Kindu et al. (2016) ecosystem valuation model.

However, locally modified ecosystem service coefficients for inland wetland biomes were not considered in the Kindu et al. (2016) study. The monetary values established per unit area from other geographically

Table 3 The six land use/land cover (LULC) categories, their biome equivalents and valuation coefficients used for ecosystem service values estimation in USD/ha/year

\begin{tabular}{lll}
\hline LULC categories & Equivalent Biome & Ecosystem service coefficients USD/ha/year (1994) \\
\hline Cultivated land & Cropland & $225.56^{\mathrm{a}}$ \\
Grazing land & Grassland & $293.25^{\mathrm{a}}$ \\
Vegetation & Tropical forest & $986.69^{\mathrm{a}}$ \\
Built-up area & Urban & 0.00 \\
Water body & Water body & $8103.50^{\mathrm{a}}$ \\
Wetland & Inland wetlands & $4204.02^{\mathrm{b}}$ \\
\hline
\end{tabular}

avalue coefficients adopted from Kindu et al. (2016). ${ }^{\mathbf{b}}$ Own modified value coefficient using the Economic of Ecosystem and Biodiversity valuation database (Van der Ploeg et al. 2010) 
Table 4 The land use/land cover categories and their corresponding ecosystem sub-service values (USD/ha/year) for six representative biomes

\begin{tabular}{|c|c|c|c|c|c|c|}
\hline \multirow[t]{2}{*}{ Ecosystem services } & \multicolumn{6}{|l|}{ Biome } \\
\hline & Cropland $^{\mathrm{a}}$ & Tropical forest $^{\mathrm{a}}$ & Urban $^{\mathrm{a}}$ & Grassland $^{a}$ & Water body ${ }^{a}$ & Wetland $^{\mathrm{b}}$ \\
\hline \multicolumn{7}{|l|}{ Provisioning services } \\
\hline Water supply & & 8.00 & & 117.45 & 2117.00 & 280.73 \\
\hline Food production & 187.56 & 32.00 & & & 41.00 & 171.10 \\
\hline Raw material & & 51.24 & & & & 198.54 \\
\hline Genetic resources & & 41.00 & & & & 45.64 \\
\hline Medicinal resources & & & & & & 33.10 \\
\hline \multicolumn{7}{|l|}{ Regulating services } \\
\hline Water regulation & & 6.00 & & 3.00 & 5445.00 & 981.84 \\
\hline Waste treatment & & 136.00 & & 87.00 & 431.50 & 1153.95 \\
\hline Erosion control & & 245.00 & & 29.00 & & 63.14 \\
\hline Climate regulation & & 223.00 & & & & 208.36 \\
\hline Biological control & 24.00 & & & 23.00 & & \\
\hline Gas regulation & & 13.68 & & 7.00 & & 67.35 \\
\hline Disturbance regulation & & 5.00 & & & & \\
\hline \multicolumn{7}{|l|}{ Supporting services } \\
\hline Nutrient cycling & & 184.40 & & 25.00 & & 103.72 \\
\hline Pollination & 12.00 & 7.27 & & 1.00 & & \\
\hline Soil formation & & 10.00 & & & & 48.50 \\
\hline Habitat/refugia & & 17.30 & & & & 716.51 \\
\hline \multicolumn{7}{|l|}{ Cultural services } \\
\hline Recreation & & 4.80 & & & 69.00 & 76.89 \\
\hline Cultural & & 2 & & 0.80 & & 54.65 \\
\hline Sum & 225.56 & 986.69 & 0.00 & 293.25 & 8103.50 & 4204.02 \\
\hline
\end{tabular}

${ }^{\mathbf{a}}$ Value coefficients adopted from Kindu et al. (2016), ${ }^{\mathbf{b}}$ Own modified value coefficient using the Economic of Ecosystem and Biodiversity valuation database (Van der Ploeg et al. 2010)

similar places were translated into our study area using benefit transfer approach as it was applied in previous research works (Kubiszewski et al. 2013; CamachoValdez et al. 2014; Richardson et al. 2014; Johnston et al. 2015). This method is crucial for developing countries like Ethiopia where resources and expertise are limited to do detailed data collection on the ground (Plummer 2009; Kubiszewski et al. 2013; Camacho-Valdez et al. 2014). Despite limitations in terms of data availability, reliability and distribution, and variation in socioeconomic and spatial heterogeneity, prominent scientists (Costanza et al. 1997, 2014; de Groot et al. 2012) used

Table 5 The total estimated area (ha) and percentage of each land use/land cover (LULC) category of Bahir Dar City from 1984 to 2019

\begin{tabular}{|c|c|c|c|c|c|c|c|c|c|c|}
\hline \multirow{2}{*}{$\begin{array}{l}\text { LULC } \\
\text { categories }\end{array}$} & \multicolumn{2}{|l|}{1984} & \multicolumn{2}{|l|}{1994} & \multicolumn{2}{|l|}{2004} & \multicolumn{2}{|l|}{2014} & \multicolumn{2}{|l|}{2019} \\
\hline & ha & $\%$ & ha & $\%$ & ha & $\%$ & ha & $\%$ & ha & $\%$ \\
\hline Cultivated land & 12,151 & 51.13 & 12,333 & 51.90 & 11,440 & 48.14 & 11,373 & 47.85 & 10,850 & 45.66 \\
\hline Built-up area & 12,031 & 5.06 & 1424 & 6.00 & 2239 & 9.42 & 2843 & 11.96 & 3802 & 16.00 \\
\hline Grazing land & 12,711 & 5.35 & 2002 & 8.43 & 1574 & 6.62 & 2088 & 8.79 & 2838 & 11.94 \\
\hline Vegetation & 4413 & 18.57 & 3467 & 14.59 & 4716 & 19.84 & 4024 & 16.93 & 3165 & 13.32 \\
\hline Water body & 612 & 2.58 & 461 & 1.94 & 543 & 2.29 & 505 & 2.12 & 350 & 1.47 \\
\hline Wetland & 4116 & 17.32 & 4078 & 17.16 & 3253 & 13.69 & 2933 & 12.34 & 2760 & 11.61 \\
\hline
\end{tabular}


the same method to estimate the global unit values of ecosystem services.

Thus, we developed valuation coefficients for each subservice of wetland systems using expert knowledge of the study landscape conditions, literature review, and valuation database of Economics of Ecosystems and Biodiversity (TEEB) (Plummer 2009; Van der Ploeg et al. 2010; Kindu et al. 2016). Care was taken to ensure that the value from TEEB valuation database can be used as a good approximation of our study area. About 44 values were selected among 1350 unique value data points from the TEEB world database complied by Van der Ploeg et al. (2010). The values were taken from tropical areas of LULC categories similar to our geographical setting and comparable socioeconomic status (Kubiszewski et al. 2013; Kindu et al. 2016). ESVs were standardized to 2007 USD/ha/year and then converted into $1994 \mathrm{USD} / \mathrm{ha} / \mathrm{year}$ to facilitate the estimation process of ESV changes to that of Kindu's value coefficients following previous study methods (Camacho-Valdez et al. 2014; Kindu et al. 2016; Yi et al. 2017). However, the standard error ( $N=$ 44; $\mathrm{SD}=364.04$ ) and deviation of the mean (SEM=54.9, Mean=280.3) that are modified for the wetland valuation coefficients are found to be in large ranges. This observation agrees with other similar studies (de Groot et al. 2012; Kubiszewski et al. 2013; Temesgen et al. 2018). Despite such limitation, many authors have used the global valuation coefficients that was developed by Costanza et al. (1997) by modifying based on the local conditions (e.g., Li et al. 2007; $\mathrm{Hu}$ et al. 2008; Kindu et al. 2016; Tianhong et al. 2010; Tolessa et al. 2017; Woldeyohannes et al. 2020).

The ESVs of each LULC category and the total ESVs of the study area over the study periods are estimated using Eqs. (2) and (3), respectively (Kreuter et al. 2001).

$$
\begin{aligned}
& \mathrm{ESV}_{k}=\sum\left(A_{k} * V C_{k}\right) \\
& \mathrm{ESV}_{f}=\sum\left(A_{k} * V C_{f k}\right)
\end{aligned}
$$

where $\mathrm{ESV}_{\mathrm{k}}$ and $\mathrm{ESV}_{\mathrm{f}}$ are ESV of LULC type " $k$ " and ESV service function " $f$ ", respectively; $A_{k}$ is the area (ha) of LULC type " $k$ "; $\mathrm{VC}_{\mathrm{k}}$ is the value coefficient of LULC type " $k$ " (USD /ha/year); and $V_{\text {fk }}$ is the value coefficient of function " $f$ " (USD/ha/yr) for LULC type " $k$ ".

Equation 3 was also applied to calculate the values of the 17 individual ecosystem services. Locally modified valuation coefficients used in this study are shown in Tables 3 and 4.

Pecrent of ESV change $=\left(\frac{\mathrm{ESV}_{\text {recent year }}-\mathrm{ESV}_{\text {previous year }}}{\mathrm{ESV}_{\text {previous year }}}\right) * 100$

The percent changes of the ESV across different periods (1984-1994, 1994-2004, 2004-2014, 2014-2019, and 1984-2019) are calculated using the formula shown in Eq. 4.

\section{Ecosystem service sensitivity analyses}

The proxy biomes for LULC types and their corresponding value coefficients used in this study were not perfect matches. Thus, it is important to conduct sensitivity analyses to ascertain the percent change in ESV over time by adjusting the value coefficients (VC). The VC of each land use type was adjusted by $50 \%$ up and down (Kreuter et al. 2001; Li et al. 2010). Here, we calculated coefficient of sensitivity (CS) using Eq. 5 (Kreuter et al. 2001; Zhao et al. 2004; Kindu et al. 2016; Yi et al. 2017):

$$
\mathrm{CS}=\frac{\left(\mathrm{ESV}_{\mathrm{j}}-\mathrm{ESV}_{\mathrm{i}}\right) / \mathrm{ESV}_{\mathrm{i}}}{\left(\mathrm{VC}_{\mathrm{jk}}-\mathrm{VC}_{\mathrm{ik}}\right) / \mathrm{VC}_{\mathrm{ik}}}
$$

where ESV is the estimated ecosystem service value, $\mathrm{VC}$ is the value coefficient, $i$ and $j$ are the initial and adjusted values, respectively, and $k$ is the land cover class (Kreuter et al. 2001). The greater the CS value is (CS always $<1$ ), the more critical the accuracy of the ecosystem service value index (Kreuter et al. 2001; Li et al. 2010).

\section{Results}

\section{Extent and trends of land use/cover changes during} 1984-2019

\section{Temporal analysis of land use/cover change}

The LULC maps of urban and peri-urban areas of Bahir Dar City produced for five reference years $(1984,1994$, 2004, 2014, and 2019) are presented in Fig. 2 and Table 5 . The major types of LULC of the peri-urban and urban areas of Bahir Dar City included cultivated land, built-up area, grazing land, vegetation, water body, and wetland. Cropland (51.13\%) was the dominant LULC type of periurban and urban areas of the city in 1984 followed by vegetation (18.6\%) and wetlands (17.3\%). The proportion of grazing land, built-up area, and water body was $5.4 \%$, $5.1 \%$, and $2.3 \%$, respectively. In 2019 , the cultivated land remained a dominant land use type (45.7\%) of the periurban and urban areas of the city followed by built-up area (16\%) and vegetations (13.3\%).

\section{The pattern of LULC change}

The LULC change trend analysis made for the four consecutive periods showed considerable land-use changes in the peri-urban and urban areas of Bahir Dar City (Table 6). As can be seen in Table 6, built-up area and grazing land had increased by $216.1 \%$ and $123.2 \%$, respectively over 35 years period. In contrast, cropland, wetlands, vegetations, and water body showed a declining trend of $10 \%, 42.8 \%, 28.3 \%$, and $33 \%$, respectively. The comparison of four study periods indicated that built-up area increased by $18.4 \%$ in the first period 

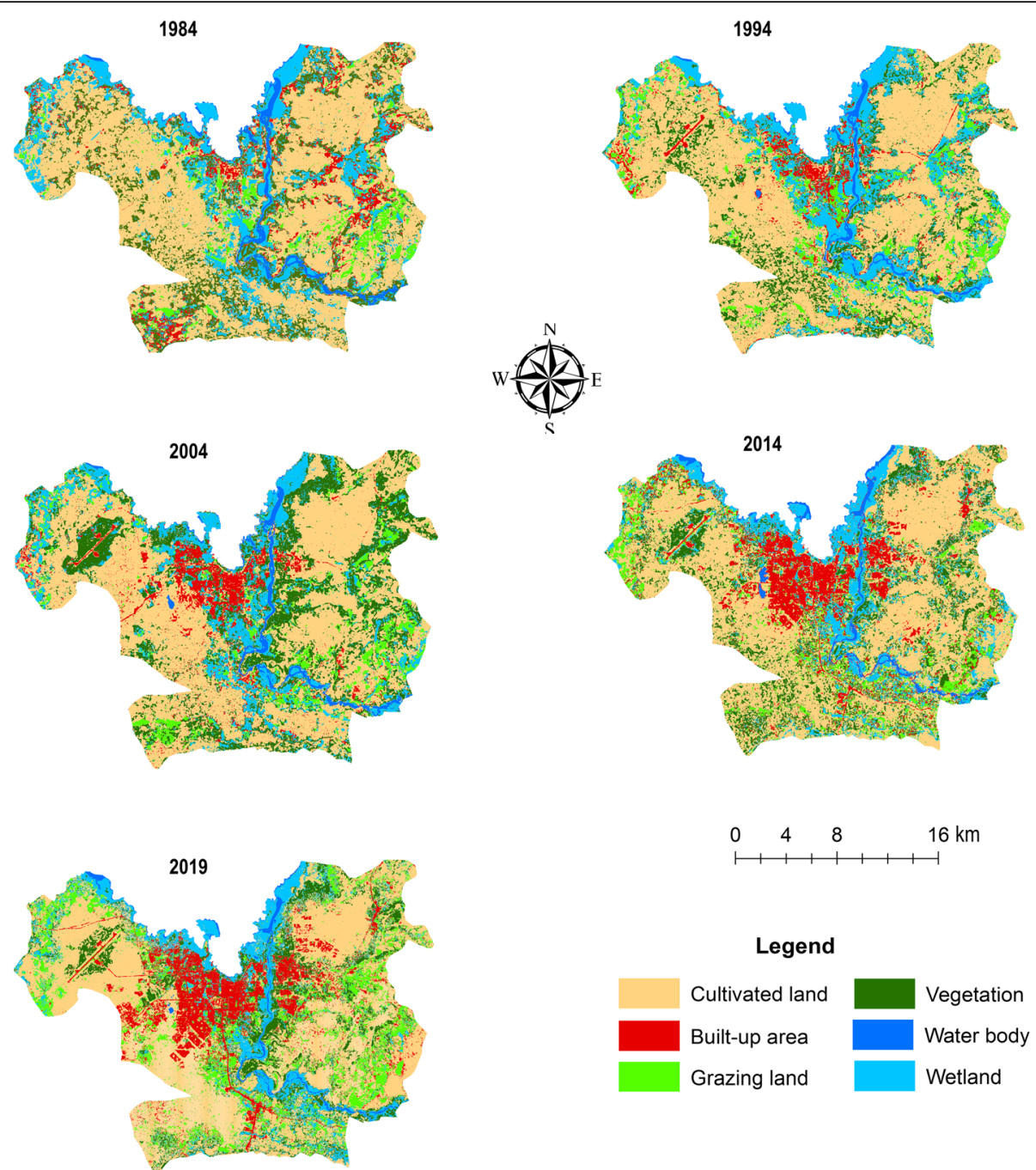

\section{Legend}

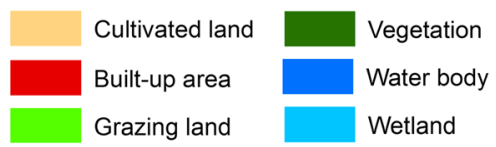

Fig. 2 The land use/land cover (LULC) map of the study area from 1984 to 2019. The LULC map is derived from the Landsat Thematic Mapper (TM), Enhanced Thematic mapper Plus $\left(\mathrm{ETM}^{+}\right)$and Operational Land Imager (OLI) satellite data

Table 6 The land use/land cover (LULC) changes (gain, loss, and rate of change) between 1984 and 1994, 2004 and 2014 , and 2014 and 2019, where $\mathrm{G}=$ gain, $\mathrm{L}=$ loss and $\mathrm{PC}=$ rate of change

\begin{tabular}{|c|c|c|c|c|c|c|c|c|c|c|}
\hline \multirow{2}{*}{$\begin{array}{l}\text { LULC } \\
\text { categories }\end{array}$} & \multicolumn{2}{|c|}{ 1984-1994 } & \multicolumn{2}{|c|}{ 1994-2004 } & \multicolumn{2}{|c|}{ 2004-2014 } & \multicolumn{2}{|c|}{ 2014-2019 } & \multicolumn{2}{|c|}{$1984-2019$} \\
\hline & G/L ha & PC \% & $\overline{G / L ~ h a}$ & PC \% & G/L ha & PC \% & G/L ha & PC \% & G/L ha & PC \% \\
\hline Cultivated land & 182 & 1.50 & -892 & -7.24 & -68 & -0.59 & -523 & -4.60 & -1301 & -10.70 \\
\hline Built-up area & 221 & 18.37 & 815 & 57.26 & 604 & 26.95 & 959 & 33.75 & 2599 & 216.07 \\
\hline Grazing land & 731 & 57.54 & -428 & -21.39 & 514 & 32.67 & 749 & 35.89 & 15676 & 123.24 \\
\hline Vegetation & -945 & -21.43 & 1248 & 36.01 & -692 & -14.66 & -859 & -21.34 & -1247 & -28.27 \\
\hline Water body & -151 & -24.69 & 82 & 17.87 & -39 & -7.14 & -154 & -30.56 & -262 & -42.76 \\
\hline Wetland & -38 & -0.92 & -825 & -20.24 & -320 & -9.84 & -173 & -5.90 & -1356 & -32.95 \\
\hline
\end{tabular}


(1984-1994), 57.3\% in the second period (1994-2004), $27 \%$ in the third period (2004-2014), and 33.8\% in the last period (2014-2019). It can be observed from Table 6 that the largest rate of increase of the builtup area per year was recorded in the last period (6.8\% per year) followed by the second period (5.7\%). Although grazing land showed a tremendous increase over the whole study period, it had declined by $21.4 \%$ in the second period then increased during two consecutive periods by $32.7 \%$ (2004-2014) and 35.9\% (2014-2019). The rate of wetland area decline also varied across the study periods; the highest rate of decline was observed in the second period $(2.03 \%$ / year) followed by the third period (1.2\%/year); in the first period, the wetland area was insignificantly declined. Similarly, vegetation and water body showed a significant decline in both study periods. The highest rate of vegetation reduction was noticed in the second period (36\%), whereas the highest reduction for water body was observed in the fourth period (30.6\%).

\section{Transformation patterns of land use types}

The change matrix analysis shows the shift of LULC from one type to the other. The highest proportion of transition occurred among cultivated, built-up area, wetlands, grassland, and vegetation LULC types over the study period. For instance, during the period between 1984 and 2019, 22.8\%, 25.1\%, and $13.14 \%$ of the wetland was changed to cultivated land, built-up area, and grazing land, respectively. This suggested that $61 \%$ of the wetland area was lost in the past 35 years. Likewise, $56.6 \%$ and $17.6 \%$ of built-up area growth was mainly the result of the shift from cultivated land (12.1\%) and grazing land (10.4\%). It was also observed that $11 \%$ of grazing

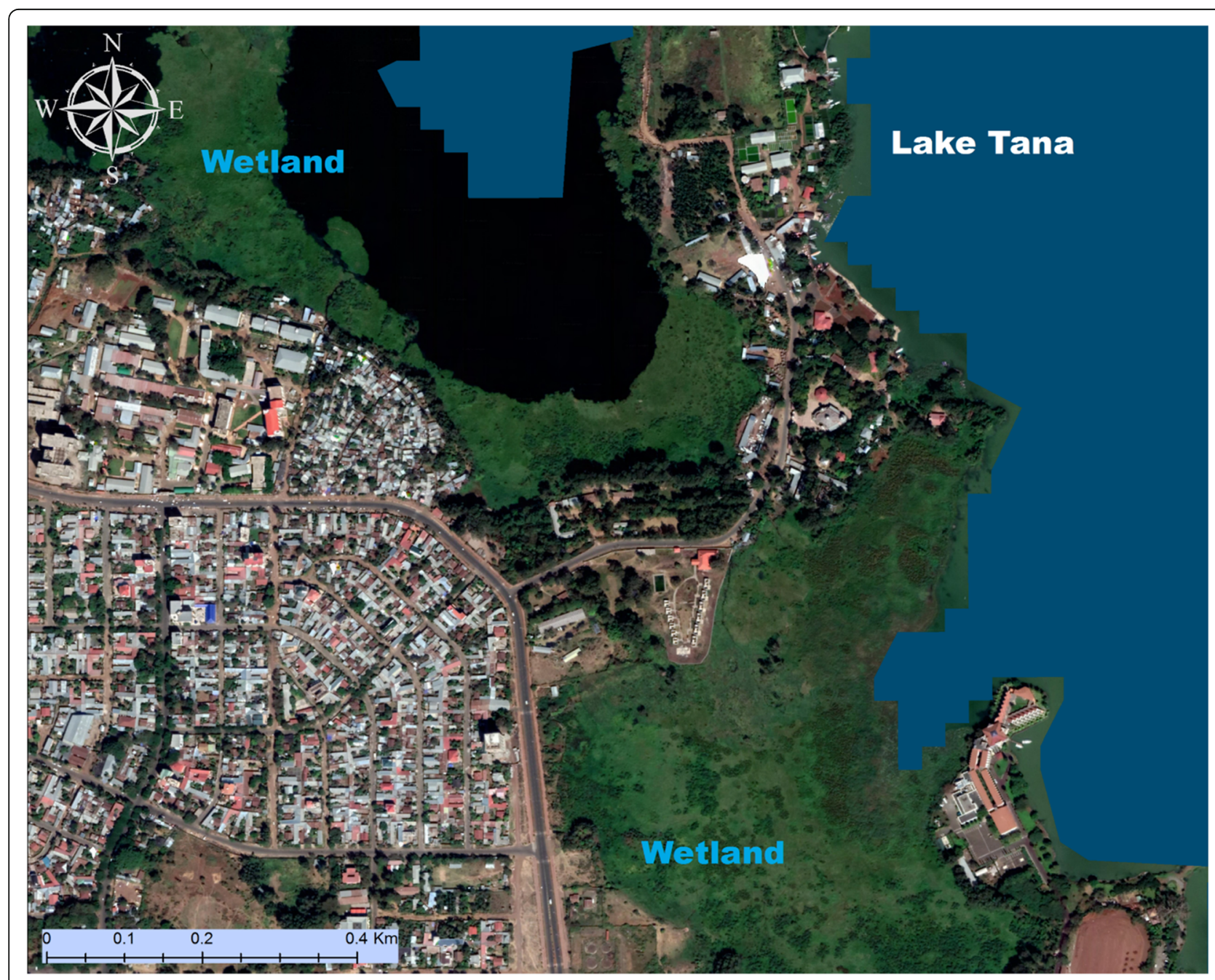

Fig. 3 A high-resolution Google-Satellite image showing part of the Bahir Dar City, where infrastructure development, residential and hotel construction are devastating lacustrine wetlands (Source: SASPlanet in 2020) 
land and $22 \%$ of vegetation land were converted to cultivated land. Generally, the largest transition was observed from cultivated land to built-up area, from wetland to built-up area, cultivated land and grazing land, and from grazing land to built-up area and cultivated lands. This implied that built-up area and cultivated land expansion have been the major threats to the deterioration of wetlands in the Bahir Dar area (Figs. 3, 4 and 5).

\section{Changes in ecosystem service values (ESV) \\ Changes in the total ecosystem service values}

The total ESV of the study area presented in Table 7 was USD $29.73 \times 10^{6}$ in 1984 . After 35 years, the total ESV had decreased to $20.84 \times 10^{6}$ (Table 7). This suggested that a total of USD $8.9 \times 10^{6}$ ESV was lost due to LULC changes from 1984 to 2019 period (Table 8). The loss of wetlands and water body were taking the majority share to the reduction of total ESV across the study periods (Table 8). As presented in Table 8, wetland and water body ESV loss has contributed to $63.9 \%$ and $24.2 \%$ of the total loss of ESV in the study area. The ESV of cultivated land and vegetation has also been reduced, whereas grazing land ESV showed small positive changes over the study period.

\section{Effects of land use/land cover changes on individual ecosystem service values}

The impacts of LULC changes on the individual ecosystem services are presented in Table 9. All evaluated 18 ecosystem services showed an overall reduction in the ESV with varying degrees between
1984 and 2019 (Table 9). Six ecosystem services such as water supply, food production, waste treatment, local climate regulation, and habitat contributed to the loss of more than $82 \%$ of the total ESV. In monetary terms, the loss of ESV from these six ecosystem services was estimated at over USD 7.31 $\times 10^{6}(82.12 \%)$ during the investigation period. Water regulation and waste treatment account for $50 \%$ (USD $4.46 \times 10^{6}$ ) of the total ESV loss mainly due to losses of wetlands including water bodies.

In 1984, the ecosystem services including water regulation (USD $7.4 \times 10^{6}$ ), waste treatment (USD $5.72 \times 10^{6}$ ), food production (USD $3.15 \times 10^{6}$ ), habitat/refugia (USD $3.03 \times 10^{6}$ ), and water supply (USD $2.64 \times 10^{6}$ ) were the principal (75\%) contributors to the total ESV (Table 9). These five ecosystem services have still dominantly contributed to the total ESV of 2019 despite significant reduction compared to 35 years ago. In a broader category, the greatest contributors to the loss of ESV for 35 years in decreasing order are regulating services, provisioning services, supporting services, and cultural services (Table 9).

\section{Ecosystem service sensitivity analyses}

Changes in the total ESV and the corresponding CS through the adjustment of $50 \%$ increase or decrease in the $\mathrm{VC}$ of each land cover type are summarized in Table 10. The $50 \%$ up and down adjustment of the total ESV coefficient values for four of the six land categories resulted in $<20 \% \quad$ (range $=0.09-0.18$ ) change in total ESV. This indicates that changes in ecosystem service coefficient values for the analysis have relatively little effect in the total ESV. By

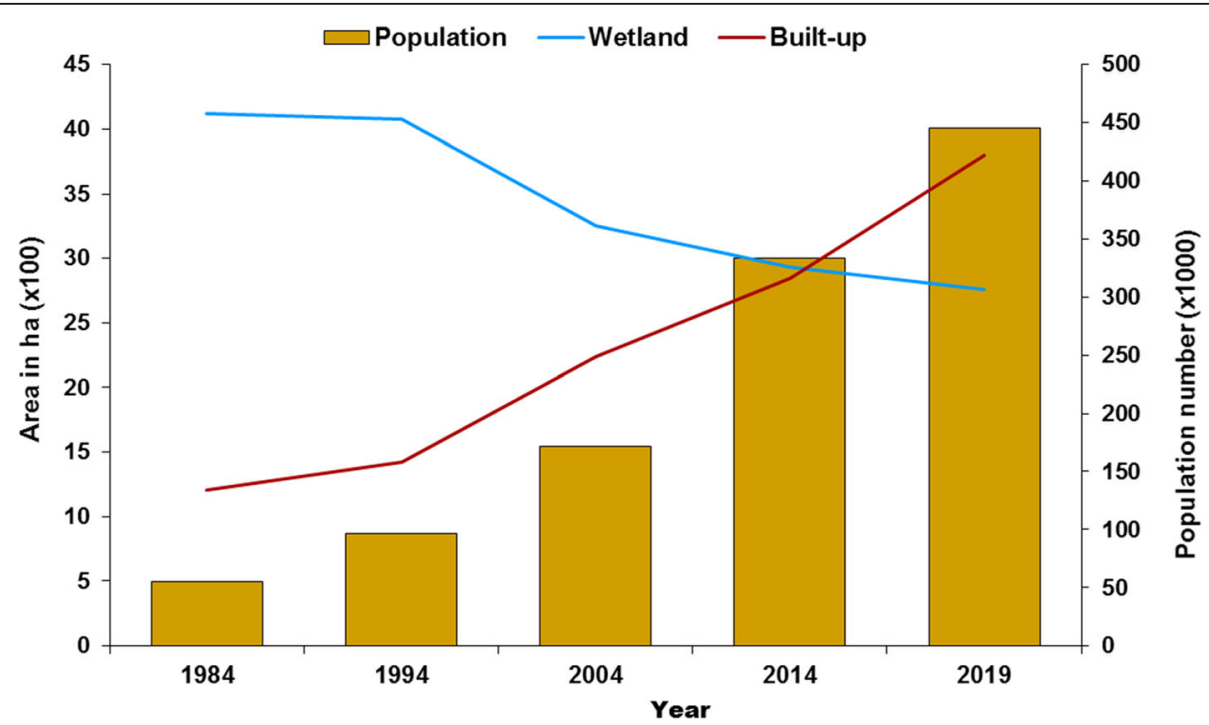

Fig. 4 Wetland shrinkage versus population growth and urban expansion over time in the study area (1984-2019). Source (Ethiopian Central Statistics Agency 1984, 1994, 2007, and 2014, 2019 projected data) 

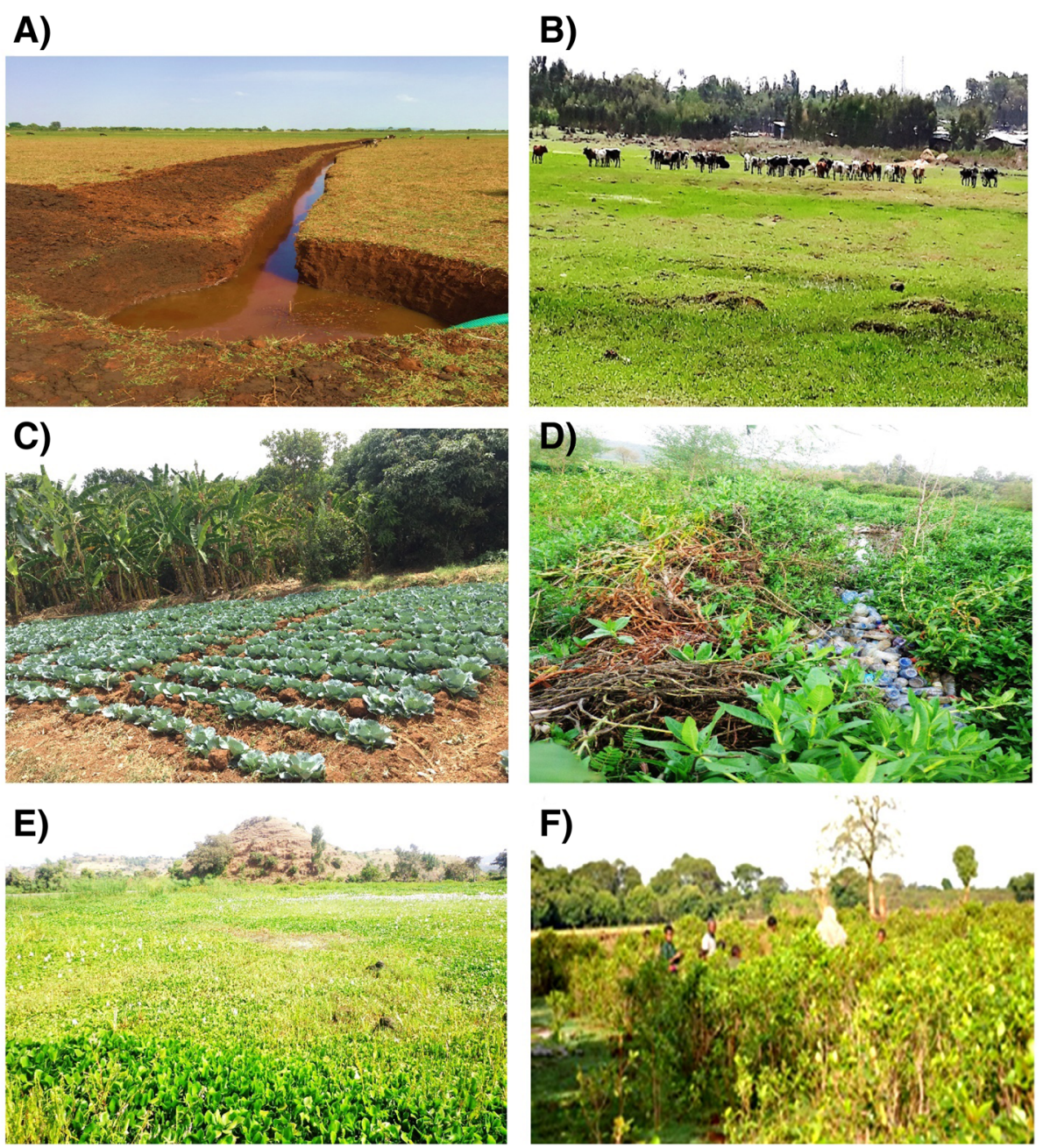

Fig. 5 Photographs showing anthropogenic activities affecting wetland ecosystem in urban and peri-urban areas of Bahir Dar City. a Water withdrawal from the wetland for irrigation. b Eucalyptus plantation and illegal settlement. $\mathbf{c}$ vegetables cultivation. $\mathbf{d}$ pollutants discharging into the wetland. e an invasion of water hyacinth on the Blue Nile riverbank, including nearby wetlands. $\mathbf{f}$ Khat cultivation

contrast, CS for wetland was relatively high $(\geq 0.531$ in all years), which implies that its VC should be computed more carefully than those of the other land cover types. When the $\mathrm{VC}$ for wetlands were adjusted by $50 \%$, the estimated ESV of the study area fluctuated from $\pm 31 \%$ to $\pm 29 \%$, while the variation in the $\mathrm{VC}$ of other land-cover types resulted in only \pm 9\% change in ESV. Grazing land was characterized by less than $2 \%$ change in ESV in response to a $50 \%$ increase or decrease in VC. Generally, the sensitivity

Table 7 The effects of land use/land cover (LULC) changes on the total ecosystem service values (ESV in USD $\times 10^{6}$ ) of Bahir Dar City

\begin{tabular}{|c|c|c|c|c|c|c|c|c|c|c|}
\hline \multirow{2}{*}{$\begin{array}{l}\text { LULC } \\
\text { categories }\end{array}$} & \multicolumn{2}{|l|}{1984} & \multicolumn{2}{|l|}{1994} & \multicolumn{2}{|l|}{2004} & \multicolumn{2}{|l|}{2014} & \multicolumn{2}{|l|}{2019} \\
\hline & ESV & $\%$ & ESV & $\%$ & ESV & $\%$ & ESV & $\%$ & ESV & $\%$ \\
\hline Cultivated land & 2.74 & 9.22 & 2.78 & 10.10 & 2.58 & 10.01 & 2.57 & 10.89 & 2.45 & 11.74 \\
\hline Built-up area & 0.00 & 0.00 & 0.00 & 0.00 & 0.00 & 0.00 & 0.00 & 0.00 & 0.00 & 0.00 \\
\hline Grazing land & 0.37 & 1.25 & 0.59 & 2.12 & 0.46 & 1.80 & 0.61 & 2.60 & 0.83 & 4.00 \\
\hline Vegetation & 4.35 & 14.64 & 3.42 & 12.36 & 4.65 & 18.05 & 4.00 & 16.85 & 3.12 & 14.98 \\
\hline Water body & 5.00 & 16.68 & 3.73 & 13.50 & 4.40 & 17.08 & 4.09 & 17.35 & 2.84 & 13.62 \\
\hline Wetland & 17.30 & 58.20 & 17.15 & 62.00 & 13.68 & 53.06 & 12.33 & 52.32 & 11.60 & 55.66 \\
\hline Total & 29.73 & & 27.67 & & 25.77 & & 23.57 & & 20.84 & \\
\hline
\end{tabular}


Table 8 Changes in ecosystem service values (ESVin USD $\times 10^{6}$ ) for each land use/land cover (LULC) category of Bahir Dar City

\begin{tabular}{|c|c|c|c|c|c|c|c|c|c|c|}
\hline \multirow{2}{*}{$\begin{array}{l}\text { LULC } \\
\text { categories }\end{array}$} & \multicolumn{2}{|c|}{ 1984-1994 } & \multicolumn{2}{|c|}{ 1994-2004 } & \multicolumn{2}{|c|}{ 2004-2014 } & \multicolumn{2}{|c|}{ 2014-2019 } & \multicolumn{2}{|c|}{ 1984-2019 } \\
\hline & $\begin{array}{l}\text { USD in } \\
\text { millions }\end{array}$ & $\begin{array}{l}\text { change } \\
\text { in } \%\end{array}$ & $\begin{array}{l}\text { USD in } \\
\text { millions }\end{array}$ & $\begin{array}{l}\text { change } \\
\text { in } \%\end{array}$ & $\begin{array}{l}\text { US D in } \\
\text { millions }\end{array}$ & $\begin{array}{l}\text { change } \\
\text { in } \%\end{array}$ & $\begin{array}{l}\text { USD in } \\
\text { millions }\end{array}$ & $\begin{array}{l}\text { change } \\
\text { in } \%\end{array}$ & $\begin{array}{l}\text { USD in } \\
\text { millions }\end{array}$ & $\begin{array}{l}\text { change } \\
\text { in } \%\end{array}$ \\
\hline $\begin{array}{l}\text { Cultivated } \\
\text { land }\end{array}$ & 0.04 & 1.91 & -0.20 & -10.53 & -0.01 & -0.46 & -0.12 & -4.35 & -0.29 & -3.25 \\
\hline Built-up area & 0.00 & 0.00 & 0.00 & 0.00 & 0.00 & 0.00 & 0.00 & 0.00 & 0.00 & 0.00 \\
\hline Grazing land & 0.22 & 10.53 & -0.13 & -6.84 & 0.15 & 6.91 & 0.22 & 7.97 & 0.46 & 5.16 \\
\hline Vegetation & -0.93 & -44.50 & 1.23 & 64.74 & -0.65 & -29.95 & -0.88 & -31.88 & -1.23 & -13.79 \\
\hline Water body & -1.27 & -60.77 & 0.67 & 35.26 & -0.31 & -14.29 & -1.25 & -45.29 & -2.16 & -24.22 \\
\hline Wetland & -0.15 & -7.18 & -3.47 & -182.63 & -1.35 & -62.21 & -0.73 & -26.45 & -5.70 & -63.90 \\
\hline Total & -2.09 & & -1.90 & & -2.17 & & -2.76 & & -8.92 & \\
\hline
\end{tabular}

Table 9 The impacts of land use/land cover changes on the individual ecosystem service values (ESV) of Bahir Dar City between 1984 and 2019

\begin{tabular}{|c|c|c|c|c|c|c|c|}
\hline \multirow[t]{2}{*}{ SN } & \multirow[t]{2}{*}{ Ecosystem services } & \multicolumn{5}{|c|}{ ESV across periods (USD in millions) } & \multirow{2}{*}{$\begin{array}{l}\text { Overall change } \\
1984-2019\end{array}$} \\
\hline & & $\mathrm{ESV}_{\mathrm{f} 1984}$ & ESV $_{\mathrm{f} 1994}$ & $\mathrm{ESV}_{\mathrm{f} 2004}$ & $\mathrm{ESV}_{\mathrm{f} 2014}$ & ESV $_{\mathrm{f} 2019}$ & \\
\hline \multirow[t]{7}{*}{1} & Provisioning services & & & & & & \\
\hline & Water supply & 2.64 & 2.38 & 2.29 & 2.17 & 1.87 & -0.76 \\
\hline & Food production & 3.15 & 3.14 & 2.88 & 2.78 & 2.62 & -0.53 \\
\hline & Raw Material & 1.04 & 0.99 & 0.89 & 0.79 & 0.71 & -0.33 \\
\hline & Genetic Resources & 0.37 & 0.33 & 0.34 & 0.30 & 0.26 & -0.11 \\
\hline & Medicinal resources & 0.14 & 0.13 & 0.11 & 0.10 & 0.09 & -0.04 \\
\hline & Sub-total & 7.34 & 6.97 & 6.51 & 6.14 & 5.55 & -1.77 \\
\hline \multirow[t]{9}{*}{2} & Regulating services & & & & & & \\
\hline & Water regulation & 7.40 & 6.54 & 6.18 & 5.66 & 4.64 & -2.76 \\
\hline & Waste treatment & 5.72 & 5.55 & 4.77 & 4.33 & 4.01 & -1.71 \\
\hline & Erosion control & 1.38 & 1.17 & 1.41 & 1.23 & 1.03 & -0.35 \\
\hline & Climate regulation & 1.84 & 1.62 & 1.73 & 1.51 & 1.28 & -0.56 \\
\hline & Biological control & 0.32 & 0.34 & 0.31 & 0.32 & 0.31 & -0.01 \\
\hline & Gas regulation & 0.35 & 0.34 & 0.29 & 0.27 & 0.25 & -0.10 \\
\hline & Disturbance regulation & 0.02 & 0.02 & 0.02 & 0.02 & 0.02 & -0.01 \\
\hline & Sub-total & 17.03 & 15.58 & 14.71 & 13.34 & 11.54 & -5.5 \\
\hline \multirow[t]{6}{*}{3} & Supporting Services & & & & & & \\
\hline & Nutrient cycling & 1.27 & 1.11 & 1.25 & 1.10 & 0.94 & -0.33 \\
\hline & Pollination & 0.18 & 0.18 & 0.17 & 0.17 & 0.15 & -0.03 \\
\hline & Soil formation & 0.24 & 0.23 & 0.20 & 0.18 & 0.17 & -0.08 \\
\hline & Habitat/refugia & 3.03 & 2.98 & 2.41 & 2.17 & 2.03 & -0.99 \\
\hline & Sub-total & 4.72 & 4.5 & 4.03 & 3.62 & 3.29 & -1.43 \\
\hline \multirow[t]{5}{*}{4} & Cultural services & & & & & & \\
\hline & Recreation & 0.38 & 0.36 & 0.31 & 0.28 & 0.25 & -0.13 \\
\hline & Cultural & 0.23 & 0.23 & 0.19 & 0.17 & 0.16 & -0.08 \\
\hline & Sub-total & 0.61 & 0.59 & 0.5 & 0.45 & 0.41 & -0.21 \\
\hline & Total & 29.71 & 27.65 & 25.75 & 23.54 & 20.80 & -8.90 \\
\hline
\end{tabular}


Table 10 Percentage change of the total estimated ecosystem service values and sensitivity coefficient (CS) after a 50\% adjustment of value coefficients (VC) for each land use/land cover type in the Bahir Dar City (1984-2019)

\begin{tabular}{|c|c|c|c|c|c|c|c|c|c|c|}
\hline \multirow{2}{*}{$\begin{array}{l}\text { Change in value } \\
\text { coefficients }\end{array}$} & \multicolumn{2}{|l|}{1984} & \multicolumn{2}{|l|}{1994} & \multicolumn{2}{|l|}{2004} & \multicolumn{2}{|l|}{2014} & \multicolumn{2}{|l|}{2019} \\
\hline & $\pm \%$ & CS & $\pm \%$ & CS & $\pm \%$ & CS & $\pm \%$ & CS & $\pm \%$ & $\mathrm{CS}$ \\
\hline Cultivated land VC $\pm 50 \%$ & 4.61 & 0.09 & 5.03 & 0.10 & 4.92 & 0.11 & 5.44 & 0.12 & 5.87 & 0.10 \\
\hline Grazing land VC $\pm 50 \%$ & 0.63 & 0.01 & 1.06 & 0.18 & 0.89 & 0.03 & 1.30 & 0.04 & 1.99 & 0.02 \\
\hline Vegetation VC $\pm 50 \%$ & 7.32 & 0.15 & 6.18 & 0.18 & 9.03 & 0.17 & 8.42 & 0.15 & 7.49 & 0.18 \\
\hline Water body VC $\pm 50 \%$ & 8.34 & 0.17 & 8.75 & 0.17 & 8.54 & 0.17 & 8.18 & 0.14 & 6.81 & 0.17 \\
\hline Wetland VC $\pm 50 \%$ & 29.10 & 0.58 & 30.98 & 0.53 & 26.53 & 0.52 & 25.67 & 0.56 & 27.83 & 0.53 \\
\hline
\end{tabular}

analysis suggests that the overall estimated ESV for the study area is likely relatively reliable despite uncertainties in the $\mathrm{VC}$ among land-cover types.

\section{Discussion}

\section{Driving forces of LULC changes}

Evidence from remote sensing image analysis showed a continuous decline of wetland areas including water bodies in the past 35 years (1984-2019) in the study area. The pronounced expansion of the built-up area to the peripheral areas of the same study area was also reported by Fitawok et al. (2020). Nevertheless, the findings of Fitawok et al. (2020) did not clearly show the extent of wetland conversions to urban areas due to the problem created during LULC classification. These authors grouped wetlands with other land cover categories (forests, pastures and water bodies). Similarly, Degife et al. (2019) reported the shrinkage of $6.4 \%$ lake area and $42.7 \%$ wetland coverage over the period of 45 years. The loss of wetland areas because of urban expansion was also reported by other studies (Zhao et al. 2004; Zorrilla-Miras et al. 2014; Gaglio et al. 2016; Belayneh et al. 2020; Rojas et al. 2019; Hailu et al. 2020). Expansion of built-up area was the main driving force for their transformation by draining, infilling and increasing the impervious areas. This has also made the ecosystems more fragmented and disconnected and thus exacerbated their ecological vulnerability (Mao et al. 2018; Huang et al. 2019). It was observed that the built-up area has been expanded since Bahir Dar City has become the capital of Amhara National Regional State. According to CSA (1994, 2007), the total number of housing units in Bahir Dar City increased from 19,808 in 1994 to 45,501 in 2007. Based on the data obtained from office of the city municipal administration, 63,820 housing units have been constructed from 2007 to 2019 of which nearly 25, 000 were constructed illegally. The rapid population growth of the city is accountable for the built-up area expansion. The trend of the city population growth presented in Fig. 4 showed the rapid increase of population from 1984 to 2020 due to rural-urban and urban-urban migration. According to housing and population census (CSA 1984, 1994, 2007) and population projection, the total population of Bahir Dar City increased from 54,800 in 1984 to 472,063 in 2020 . In other words, the city's population has increased by $761 \%$ which is equivalent to 11,591 people/year in the past 36 years. Similar trends were reported in other studies (Hurni et al. 2005; Gebrelibanos and Assen 2015; Gashaw et al. 2017; Hussien et al. 2018; Berihun et al. 2019; Degife et al. 2019; Desta and Fetene 2020; Hailu et al. 2020).

The building of infrastructures, social services, and different market centers in line with residential houses have also contributed to the shrinkage of wetlands, cultivated land, water body, vegetation, and grazing land. The findings of the study by Gashu and GebreEgziabher (2018) revealed that the area covered by roads, urban parks, roundabouts, public squares and plaza, business building, industrial parks, medians, and sport fields had expanded by $11 \%$ from 1975 to 2015 while the growth of the residential area was $10 \%$. Several studies have showed the conversion of wetlands and other LULC (farmland, forest, grassland, shrubland, and woodland) into built-up areas because of rapid growth of urbanization (e.g., Zhao et al. 2004; Anteneh et al. 2018; Degife et al. 2019; Hailu et al. 2020). Lee et al. (2006) demonstrated that rapid urbanization at the expense of wetland ecosystems posed ecological threats such as the changes in hydrological and sedimentation regimes, and the dynamics of nutrients and pollutants. Consequently, the ecological services provided by urban wetlands have been compromised (Ehrenfeld 2000; Lee et al. 2006).

Despite the declining trend of the cultivated land due to built-up areas expansion, farming practices have also contributed to the loss of wetlands in the peri-urban areas of Bahir Dar City. Since khat is a more valuable crop per unit area than cereal crop, smallholder farmers of the peri-urban areas have shifted cereal crop production into khat plantation (Berihun et al. 2019). The study conducted by Worku (2018) revealed that khat (Catha edulis) plantation had been expanded by $76 \%$ from 2001 to 2016 at expense of cereal crop farmlands in the periurban areas of Bahir Dar City. The plantation of khat has mostly taken place in the peripheries and within wetlands. Khat farms are irrigated by water diverted from the wetlands thereby resulting in extensive wetland 
drainage. This result is consistent with the findings of McCauley et al. (2015), which reported that the surface areas of wetlands used for irrigation agriculture were drained 197\% more than those wetlands with no agricultural irrigation.

The illegal encroachment of farmland into the wetlands exacerbated their shrinkage in the peri-urban areas of the study area. During discussions, the participants reported that large area of the wetlands were converted to cultivated lands illegally. The decline of farmland holding per household and the increasing of landless young people caused illegal encroachment of wetlands. The local government officials have also been allocating wetlands for landless young households. This is in agreement with the research findings of Getenet and Tefera (2017) and Enyew et al. (2020). Getenet and Tefera (2017) reported that farmers with legally owned land in the wetland's peripheries cultivated wetlands illegally. The size of illegally cultivated wetland parts ranged from 0.5 to 4 ha per farmer. The council of kebele administrations has intentionally ignored wetland encroachment believing that it could solve the shortage of farmland (Getenet and Tefera 2017). The effect of the growing number of the landless people in line with unemployment on LULC was also reported in southwestern Ethiopia (Hailu et al. 2020).

\section{Changes in ecosystem service values}

Our analysis indicated that the total ESV of the study area has decreased by USD $8.9 \times 10^{6}$ from 1984 to 2019 . The loss (USD $26.12 \times 10^{6}$ ) was even worse considering global valuation coefficients from Costanza et al. (2014). This estimation is nearly three times higher than the adopted local value coefficients. A marked decline in the total ESV was primarily associated with the reduction in the ESV of wetland, vegetation, and water body. Wetland loss represents the majority of the total decline in the ecosystem services values in the study area because it has a high value coefficient. This is in agreement with the findings of Msofe et al. (2020), who found that wetland conversion accounted for the highest share of the total ESV reduction in the Kilombero Valley Floodplain (Tanzania). Likewise, Zhao et al. (2004) reported the decrease of total ESV from USD 316.77 to 120.40 million per year in Dongtan (China) between 1990 and 2000, largely due to a 71\% loss of wetlands. Similar reductions of total ESV were also reported in various Ethiopian landscapes. For instance, the conversion of forests, woodland, shrubland, and bushland had contributed to the lion share for the loss of ecological service values in the Munessa-Shashemene watershed (Kindu et al. 2016, 2018), Chillimo forest (Tolessa et al. 2017), and Abaya-Chamo basin (Woldeyohannes et al. 2020). Contrary to our finding, a study conducted in Nigeria showed a slight increase in total ESV despite a significant decrease in forest cover (Arowolo et al. 2018). Among other reasons, the difference in the valuation coefficients used could be the cause of this situation.

The change in LULC progressively diminished the total ESV of the land during the study periods. The trend of ESV reduction is quite similar although it has a higher value than reported in the prior studies (Kindu et al. 2016; Tolessa et al. 2017; Gashaw et al. 2018). This could be related to the use of different LULC categories that determine the selection of global valuation coefficients. In our classification, wetland and water biomes, among others that had higher coefficients of value, were taken into consideration.

\section{Impacts of LULC changes on the individual ecosystem service value}

Changes in LULC have resulted in a continuous decline of almost all individual ecosystem services during the study periods. This decline is mainly explained by the reduction in wetland coverage, which in turn leads to loss of ecosystem services essential to water regulation, waste treatment, and habitats for maintenance of biodiversity. The significant reduction of these important ecological services over 35 years could affect flood tolerance and waste assimilation potentials of Bahir Dar City, making it more susceptible to flood and contamination. Various studies have confirmed the adverse effect of LULC change on several ecosystem services. For instance, a decrease in vegetation cover (forests, woodland/shrub/bushland) has led to the decline of many individual ecosystem service values in other parts of Ethiopia (Kindu et al. 2016; Tolessa et al. 2017; Gashaw et al. 2018; Woldeyohannes et al. 2020). Likewise, urban and agricultural pressures on other land resources have brought the reductions of several ecosystem services in China (Zhao et al. 2004; Liang et al. 2017; Jiang et al. 2019), Puget Sound-USA (Zank et al. 2016), and Nigeria (Arowolo et al. 2018). The changes in LULC in Bahir Dar and the peri-urban area have brought significant impacts both on the individual and total ecosystem service values. This suggested the need for intervention to maintain wetlands for stormwater management, water supply, water treatment, and recreation roles (McInnes 2013).

Payment for Ecosystem Services (PES) or incentives for ecosystem services (IES) can be seen as an alternative conservation strategy to address the loss of ecosystem services associated with urbanization (Jiangyi et al. 2020). Implementation of PES would be successfully carried out if the intervention areas of PES are identified through ecosystem-based spatial planning and strategic environment assessment (Dhyani et al. 2018; Ferreira et al. 2019). Additionally, creating green infrastructure in the urban and peri-urban areas, restoration of degraded wetlands with native plants and promotion of 
environmental education could help maintain the functioning of ecosystem service flows (Ethiopian Wildlife and Natural History Society (EWNHS) 2018; Douglas 2018; du Toit et al. 2018).

\section{Limitation of the study}

Despite providing important information, this study has some limitations. Its major limitation stems from the difficulty of classifying wetland, vegetation, and built-up areas. Our LULC data are generated using 30-m Landsat images with acceptable precision and a Kappa coefficient. Classifying LULC using 30-m Landsat images likely leads to classification errors. Identifying wetlands from other LULC types is difficult because wetlands are made up of a variety of entities that can potentially be blended with vegetation, grazing land, and cultivated land. Built-up areas may also be mixed with black soil and waterbodies. Separating natural forests from permanent crops is another challenge confronting us during satellite image classification. Under this circumstance, the loss of ecosystem service values may be underestimated or overestimated as a result of LULC dynamics. Besides, the images could not be classified in detail due to the limited resolution of remote sensing images (Arowolo et al. 2018). Thus, we suggest the use of satellite imagery with higher spatial resolution.

\section{Conclusions}

This study evaluated the impacts of LULC changes on the urban wetland ecosystem services in Bahir Dar City over 35 years (1984-2019). The findings displayed severe decline ( -1618 ha) of wetlands and water bodies, largely because of built-up area and cultivated land expansion. The changes in the ESVs during the study periods indicated that LULC dynamics driven primarily by urban growth adversely affected the ecosystem services provided by wetlands and other landcovers. Our results have shown a substantial reduction of ESVs in the urban and peri-urban areas of Bahir Dar City. The total ESV which was estimated at USD $29.73 \times 10^{6}$ in 1984 had declined to USD $20.84 \times 10^{6}$ in 2019 . This indicates that approximately USD $8.9 \times 10^{6}$ ESV had lost over 35 years. This was connected with the decrease in the ESV of wetland, water body, and vegetation. Moreover, LULC changes resulted in a loss of individual ecosystem services that were essential to water regulation, waste treatment, and habitats for the maintenance of biodiversity. The significant reduction of these important ecological services could affect flood tolerance and waste assimilation potentials of Bahir Dar City, making it more susceptible to flooding and contamination. In general, the results confirmed the existence of a conflict between the sustainable delivery of ecosystem services and urban expansion. In particular, policy-makers and urban planners should develop land-use planning that help to reconcile urban development and wetland conservation.

\section{Abbreviations}

CSA: Central Statistical Authority; CS: Coefficient of sensitivity; DEM: Digital elevation model; LULC: Land-use/land-cover; ESV: Ecosystem service values; MEA: Millennium ecosystem assessment; TEEB: The economics of ecosystems and biodiversity; PES: Payment for ecosystem services; IES: Incentives for ecosystem services

\section{Acknowledgements}

We are grateful to the USGS for providing free Landsat images and DEM data. We thank the people involved in gathering ground truth data. We also thank the anonymous reviewers for their valuable comments that helped us greatly to improve the manuscript.

\section{Authors' contributions}

WWA designed the study and collected data accordingly. He analyzed the satellite imagery, interpreted the results, and prepared the manuscript. BGE contributed in the interpretation of the research findings and literature review. He also edited, commented, and improved the English language of the final manuscript. AW edited and commented the manuscript. Finally, all authors read and endorsed the final manuscript for publication.

\section{Authors' information}

Workiyie Worie Assefa is a lecturer (Asst. Prof.) at the Department of Biology and a member of the research staff of the Blue Nile Water Institute, Bahir Dar University, Bahir Dar, Ethiopia. He received a Master of Science from the University of Addis Ababa (Ethiopia) and the European University Consortium (University of Basque Spain, University of Bordeaux-France, University of Liège-Belgium). Currently, He is a Ph.D. candidate in the School of Fisheries and Wildlife, College of Agriculture and Environmental Sciences, Bahir Dar University, Bahir Dar, Ethiopia.

\section{Funding}

This research received no external funding.

Availability of data and materials

All data are included in the manuscript.

\section{Declarations}

Ethics approval and consent to participate

Not applicable.

\section{Consent for publication}

All authors agreed and approved the manuscript for publication in Ecological Processes.

\section{Competing interests}

The authors declare that they have no competing interests.

\section{Author details}

'Department of Biology, College of Science, Blue Nile Water Institute, Bahir Dar University, P.O. Box 79, Bahir Dar, Ethiopia. ${ }^{2}$ College of Social Science, Blue Nile Water Institute, Bahir Dar University, P.O. Box 79, Bahir Dar, Ethiopia. ${ }^{3}$ School of Fisheries and Wildlife, College of Agriculture and Environmental Sciences, Bahir Dar University, P.O. Box 79, Bahir Dar, Ethiopia.

Received: 26 December 2020 Accepted: 6 May 2021

Published online: 08 June 2021

\section{References}

Adam AG (2014) Informal settlements in the peri-urban areas of Bahir Dar, Ethiopia: An institutional analysis. Habitat Int 43:90-97. https://doi.org/10.101 6/j.habitatint.2014.01.014

Adamowicz W, Bunch D, Cameron TA, Dellaert BGC, Hanneman M, Keane M, Louviere J, Meyer R, Steenburgh T, Swait J (2008) Behavioral frontiers in choice modeling. Mark Lett 19(3-4):215-228. https://doi.org/10.1007/s11002008-9038-1

Addisu S, Selassie YG, Fissha G, Gedif B (2015) Time series trend analysis of temperature and rainfall in lake Tana Sub-basin, Ethiopia. Environ Syst Res 4(1):25. https://doi.org/10.1186/s40068-015-0051-0 
Admasu WF, Boerema A, Nyssen J, Minale AS, Tsegaye EA, van Passel S (2020) Uncovering ecosystem services of expropriated land: the case of urban expansion in Bahir Dar, Northwest Ethiopia. Land 9(10):395. https://doi.org/1 0.3390/land9100395

Anaya-Romero M, Muñoz-Rojas M, Ibáñez B, Marañón T (2016) Evaluation of forest ecosystem services in Mediterranean areas. A regional case study in South Spain. Ecosyst Serv 20:82-90. https://doi.org/10.1016/j.ecoser.2016.07. 002

Aneseyee AB, Soromessa T, Elias E (2019) The effect of land use/land cover changes on ecosystem services valuation of Winike watershed, Omo Gibe basin, Ethiopia. Hum Ecol Risk Assess 26(10):2608-2627. https://doi.org/10.1 080/10807039.2019.1675139

Anteneh Y, Stellmacher T, Zeleke G, Mekuria W, Gebremariam E (2018) Dynamics of land change: insights from a three-level intensity analysis of the Legedadie-Dire catchments, Ethiopia. Environ Monit Assess 190(5):309. https://doi.org/10.1007/s10661-018-6688-1

Arowolo AO, Deng X, Olatunji OA, Obayelu AE (2018) Assessing changes in the value of ecosystem services in response to land-use/land-cover dynamics in Nigeria. Sci Total Environ 636:597-609. https://doi.org/10.1016/j.scitotenv.201 8.04.277

Assefa WW, Beneberu G, Sitotaw B, Wondie A (2020) Biological monitoring of freshwater ecosystem health in Ethiopia: A review of current efforts, challenges, and future developments. Ethiop J Sci Technol 13(3):229-264. https://doi.org/10.4314/ejst.v13i3.5

Badamfirooz J, Mousazadeh R (2019) Quantitative assessment of land use/land cover changes on the value of ecosystem services in the coastal landscape of Anzali International Wetland. Environ Monit Assess 191(11):694. https://doi. org/10.1007/s10661-019-7802-8

Balthazar V, Vanacker V, Molina A, Lambin EF (2015) Impacts of forest cover change on ecosystem services in high Andean mountains. Ecol Indic 48:6375. https://doi.org/10.1016/j.ecolind.2014.07.043

Belayneh Y, Ru G, Guadie A, Teffera ZL, Tsega M (2020) Forest cover change and its driving forces in Fagita Lekoma District, Ethiopia. J For Res 31(5):15671582

Berihun ML, Tsunekawa A, Haregeweyn N, Meshesha DT, Adgo E, Tsubo M, Masunaga T, Fenta AA, Sultan D, Yibeltal M (2019) Exploring land use/land cover changes, drivers and their implications in contrasting agro-ecological environments of Ethiopia. Land Use Policy 87:104052. https://doi.org/10.101 6/j.landusepol.2019.104052

Breiman L (2001) Random Forests. Mach Learn 45(1):5-32. https://doi.org/10.1 023/A:1010933404324

Camacho-Valdez V, Ruiz-Luna A, Ghermandi A, Berlanga-Robles CA, Nunes PALD (2014) Effects of land use changes on the ecosystem service values of coastal wetlands. Environ Manage 54(4):852-864. https://doi.org/10.1007/s00267-0140332-9

Chander G, Markham BL, Helder DL (2009) Summary of current radiometric calibration coefficients for Landsat MSS, TM, ETM+, and EO-1 ALI sensors. Remote Sens Environ 113(5):893-903. https://doi.org/10.1016/j.rse.2009.01.007

Chavez PS (1996) Image-based atmospheric corrections - revisited and improved. Photogramm Eng Remote Sens 62:1025-1036

Congalton RG (1991) A review of assessing the accuracy of classifications of remotely sensed data. Remote Sens Environ 37(1):35-46. https://doi.org/10.1 016/0034-4257(91)90048-B

Costanza R, D'Arge R, de Groot R et al (1997) The value of the world's ecosystem services and natural capital. Nature 387(6630):253-260. https://doi.org/10.103 8/387253a0

Costanza R, de Groot R, Sutton P, van der Ploeg S, Anderson SJ, Kubiszewski I, Farber S, Turner RK (2014) Changes in the global value of ecosystem services. Glob Environ Chang 26:152-158. https://doi.org/10.1016/j.gloenvcha.2014.04.002

CSA (1984) Federal Democratic Republic of Ethiopia Office of Population and Housing Census Commission Central Statistical Authority: The 1984 Population and Housing Census of Ethiopia Result Analytical Report. Centra Statistical Authority, Addis Ababa

CSA (1994) Federal Democratic Republic of Ethiopia Office of Population and Housing Census Commission Central Statistical Authority: The 1994 Population and Housing Census of Ethiopia Result Analytical Report. Central Statistical Agency, Addis Ababa

CSA (2007) Federal Democratic Republic of Ethiopia Office of Population and Housing Census Commission Central Statistical Authority: The 2007 Population and Housing Census of Ethiopia Result Analytical Report. Central Statistical Agency, Addis Ababa
Davidson NC (2014) How much wetland has the world lost? Long-term and recent trends in global wetland area. Mar Freshw Res 65(10):934-941. https:// doi.org/10.1071/MF14173

de Groot R, Brander L, van der Ploeg S, Costanza R, Bernard F, Braat L, Christie M, Crossman N, Ghermandi A, Hein L, Hussain S, Kumar P, McVittie A, Portela R, Rodriguez LC, ten Brink P, van Beukering P (2012) Global estimates of the value of ecosystems and their services in monetary units. Ecosyst Serv 1(1): 50-61. https://doi.org/10.1016/j.ecoser.2012.07.005

Degife A, Worku H, Gizaw S, Legesse A (2019) Land use land cover dynamics, its drivers and environmental implications in Lake Hawassa Watershed of Ethiopia. Remote Sens Appl Soc Environ 14:178-190. https://doi.org/10.1016/ j.rsase.2019.03.005

Desta H, Fetene A (2020) Land-use and land-cover change in Lake Ziway watershed of the Ethiopian Central Rift Valley Region and its environmental impacts. Land Use Policy 96:104682. https://doi.org/10.1016/j.landusepol.202 0.104682

Dhyani S, Lahoti S, Khare S, Pujari P, Verma P (2018) Ecosystem based Disaster Risk Reduction approaches (EbDRR) as a prerequisite for inclusive urban transformation of Nagpur City, India. Int J Disaster Risk Reduct 32:95-105. https://doi.org/10.1016/j.ijdrr.2018.01.018

Douglas I (2018) The challenge of urban poverty for the use of green infrastructure on floodplains and wetlands to reduce flood impacts in intertropical Africa. Landsc Urban Plan 180:262-272. https://doi.org/10.1016/j. landurbplan.2016.09.025

du Toit MJ, Cilliers SS, Dallimer M, Goddard M, Guenat S, Cornelius SF (2018) Urban green infrastructure and ecosystem services in sub-Saharan Africa. Landsc Urban Plan 180:249-261. https://doi.org/10.1016/j.landurbplan.2018.06.001

Ehrenfeld JG (2000) Evaluating wetlands within an urban context. Urban Ecosyst 4(1):69-85. https://doi.org/10.1023/A:1009543920370

Enyew BG, Assefa WW, Gezie A (2020) Socioeconomic effects of water hyacinth (Echhornia crassipes) in Lake Tana, North Western Ethiopia. PLoS One 15(9): e0237668. https://doi.org/10.1371/journal.pone.0237668

Ethiopian Wildlife and Natural History Society (EWNHS) (2018) A First Directory of Ethiopian Wetlands: Descriptions, Ecosystem Services, Causes of Degradation $\&$ Recommendations for Restoration and Sustainability. Eclipse Printing and Graphics, Addis Ababa

Fenta AA, Yasuda H, Haregeweyn N, Belay AS, Hadush Z, Gebremedhin MA, Mekonnen G (2017) The dynamics of urban expansion and land use/land cover changes using remote sensing and spatial metrics: the case of Mekelle City of northern Ethiopia. Int J Remote Sens 38(14):4107-4129. https://doi. org/10.1080/01431161.2017.1317936

Ferreira LMR, Esteves LS, de Souza EP, dos Santos CAC (2019) Impact of the urbanisation process in the availability of ecosystem services in a tropical ecotone area. Ecosystems 22(2):266-282. https:/doi.org/10.1007/s10021-018-0270-0

Fitawok MB, Derudder B, Minale AS, van Passel S, Adgo E, Nyssen J (2020) Modeling the impact of urbanization on land-use change in Bahir Dar City, Ethiopia: an Integrated Cellular Automata-Markov Chain Approach. Land 9(4): 115. https://doi.org/10.3390/land9040115

Gaglio M, Aschonitis VG, Gissi E, Castaldelli G, Fano EA (2016) Land use change effects on ecosystem services of river deltas and coastal wetlands: case study in Volano-Mesola-Goro in Po river delta (Italy). Wetl Ecol Manag 25(1):67-86. https://doi.org/10.1007/s11273-016-9503-1

Gashaw T, Tulu T, Argaw M, Worglul AW (2017) Evaluation and prediction of land use/land cover changes in the Andassa watershed, Blue Nile Basin, Ethiopia. Environ Syst Res 6(1):17. https://doi.org/10.1186/s40068-017-0094-5

Gashaw T, Tulu T, Argaw M, Worqlul AW, Tolessa T, Kindu M (2018) Estimating the impacts of land use/land cover changes on Ecosystem Service Values: The case of the Andassa watershed in the Upper Blue Nile basin of Ethiopia. Ecosyst Serv 31:219-228. https://doi.org/10.1016/j.ecoser.2018.05.001

Gashu K, Gebre-Egziabher T (2018) Spatiotemporal trends of urban land use/land cover and green infrastructure change in two Ethiopian cities: Bahir Dar and Hawassa. Environ Syst Res 7(1):8. https://doi.org/10.1186/s40068-018-0111-3

Gebrelibanos T, Assen M (2015) Land use/land cover dynamics and their driving forces in the Hirmi watershed and its adjacent agro-ecosystem, highlands of Northern Ethiopia. J Land Use Sci 10(1):81-94. https://doi.org/10.1080/174 $7423 \times .2013 .845614$

Getenet B, Tefera B (2017) Institutional Analysis of Environmental Resource Management in Lake Tana Sub-basin. In: Stave K, Goshu G, Aynalem S (eds) Social and ecological system dynamics: characteristics, trends, and integration in the Lake Tana Basin, Ethiopia. Springer International Publishing, Cham, pp 453-477. https://doi.org/10.1007/978-3-319-45755-0_27 
Hailu A, Mammo S, Kidane M (2020) Dynamics of land use, land cover change trend and its drivers in Jimma Geneti District, Western Ethiopia. Land Use Policy 99:105011. https://doi.org/10.1016/j.landusepol.2020.105011

Haregeweyn N, Fikadu G, Tsunekawa A, Tsubo M, Meshesha DT (2012) The dynamics of urban expansion and its impacts on land use/land cover change and small-scale farmers living near the urban fringe: a case study of Bahir Dar, Ethiopia. Landsc Urban Plan 106(2):149-157. https://doi.org/10.101 6/j.landurbplan.2012.02.016

Hasan S, Shi W, Zhu X (2020) Impact of land use land cover changes on ecosystem senvice value - A case study of Guangdong, Hong Kong, and Macao in South China. PLoS One 15(4):e0231259. https:/doi.org/10.1371/journal.pone.0231259

Heintzman LJ, McIntyre NE (2019) Quantifying the effects of projected urban growth on connectivity among wetlands in the Great Plains (USA). Landsc Urban Plan 186:1-12. https://doi.org/10.1016/j.landurbplan.2019.02.007

Hu H, Liu W, Cao M (2008) Impact of land use and land cover changes on ecosystem services in Menglun, Xishuangbanna, Southwest China. Environ Monit Assess 146(1-3):147-156. https://doi.org/10.1007/s10661-007-0067-7

Huang Q, Zhao X, He C, Yin D, Meng S (2019) Impacts of urban expansion on wetland ecosystem services in the context of hosting the Winter Olympics: a scenario simulation in the Guanting Reservoir Basin, China. Reg Environ Chang 19(8):2365-2379. https://doi.org/10.1007/s10113-019-01552-1

Hurni H, Tato K, Zeleke G (2005) The implications of changes in population, land use, and land management for surface runoff in the Upper Nile Basin Area of Ethiopia. Mt Res Dev 25:147-154. https://doi.org/10.1659/0276-4741(2005)02 5[0147:TIOCIP]2.0.CO;2.

Hussien K, Demissie B, Meaza H (2018) Spatiotemporal wetland changes and their threats in North Central Ethiopian Highlands. Singapore J Trop Geogr 39(3):332-350.

Jiang Z, Sun X, Liu F, Shan R, Zhang W (2019) Spatio-temporal variation of land use and ecosystem service values and their impact factors in an urbanized agricultural basin since the reform and opening of China. Environ Monit Assess 191(12):739. https://doi.org/10.1007/s10661-019-7896-z

Jiangyi L, Shiquan D, El Housseine HA (2020) Cost-effectiveness analysis of different types of payments for ecosystem services: a case in the urban wetland ecosystem. J Clean Prod 249:119-325. https://doi.org/10.1016/j. jclepro.2019.119325

Jin Y, Liu X, Chen Y, Liang X (2018) Land-cover mapping using Random Forest classification and incorporating NDVI time-series and texture: a case study of central Shandong. Int J Remote Sens 39(23):8703-8723. https://doi.org/10.1 080/01431161.2018.1490976

Johnston RJ, Rolfe J, Rosenberger RS, Brouwer R (2015) Benefit transfer of environmental and resource values. Springer Netherlands, Dordrecht. https:// doi.org/10.1007/978-94-017-9930-0

Kentula ME, Gwin SE, Pierson SM (2004) Tracking changes in wetlands with urbanization: Sixteen years of experience in Portland, Oregon, USA. Wetlands 24(4): 734-743. https://doi.org/10.1672/0277-5212(2004)024[0734:TCIMWU]2.0.CO;2

Kindu M, Schneider T, Döllerer M, Teketay D, Knoke T (2018) Scenario modelling of land use/land cover changes in Munessa-Shashemene landscape of the Ethiopian highlands. Sci Total Environ 622-623:534-546. https://doi.org/10.1 016/j.scitotenv.2017.11.338

Kindu M, Schneider T, Teketay D, Knoke T (2016) Changes of ecosystem service values in response to land use/land cover dynamics in MunessaShashemene landscape of the Ethiopian highlands. Sci Total Environ 547: 137-147. https://doi.org/10.1016/j.scitotenv.2015.12.127

Kreuter UP, Harris HG, Matlock MD, Lacey RE (2001) Change in ecosystem service values in the San Antonio area, Texas. Ecol Econ 39(3):333-346. https://doi. org/10.1016/S0921-8009(01)00250-6

Kubiszewski I, Costanza R, Dorji L, Thoennes P, Tshering K (2013) An initial estimate of the value of ecosystem services in Bhutan. Ecosyst Serv 3:e11e21. https://doi.org/10.1016/j.ecoser.2012.11.004

Lee SY, Dunn RJK, Young RA et al (2006) Impact of urbanization on coastal wetland structure and function. Austral Ecol 31(2):149-163. https://doi.org/1 0.1111/j.1442-9993.2006.01581.x

Leh MDK, Matlock MD, Cummings EC, Nalley LL (2013) Quantifying and mapping multiple ecosystem services change in West Africa. Agric Ecosyst Environ 165:6-18. https://doi.org/10.1016/j.agee.2012.12.001

Li J, Wang W, Hu G, Wei Z (2010) Changes in ecosystem service values in Zoige Plateau, China. Agric Ecosyst Environ 139(4):766-770. https://doi.org/10.1016/ j.agee.2010.10.019

Li R-Q, Dong M, Cui J-Y, Zhang LL, Cui QG, He WM (2007) Quantification of the impact of land-use changes on ecosystem services: a case study in Pingbian
County, China. Environ Monit Assess 128(1-3):503-510. https://doi.org/10.1 007/s10661-006-9344-0

Liang J, Zhong M, Zeng G, Chen G, Hua S, Li X, Yuan Y, Wu H, Gao X (2017) Risk management for optimal land use planning integrating ecosystem services values: a case study in Changsha, Middle China. Sci Total Environ 579:16751682. https://doi.org/10.1016/j.scitotenv.2016.11.184

Lillesand T, Kiefer RW, Chipman J (2015) Remote sensing and image interpretation, 7th edn. Wiley, Madison, Wisconsin

Liu Y, Hou X, Li X, Song B, Wang C (2020) Assessing and predicting changes in ecosystem service values based on land use/cover change in the Bohai Rim coastal zone. Ecol Indic 111:106004. https://doi.org/10.1016/j.ecolind.2019.1 06004

Liu Y, Li J, Zhang H (2012) An ecosystem service valuation of land use change in Taiyuan City, China. Ecol Model 225:127-132. https://doi.org/10.1016/j. ecolmodel.2011.11.017

Mao D, Wang Z, Wu J, Wu B, Zeng Y, Song K, Yi K, Luo L (2018) China's wetlands loss to urban expansion. Land Degrad Dev 29(8):2644-2657. https://doi.org/1 0.1002/ldr.2939

McCauley LA, Anteau MJ, van der Burg MP, Wiltermuth MT (2015) Land use and wetland drainage affect water levels and dynamics of remaining wetlands. Ecosphere 6:art92. https://doi.org/10.1890/ES14-00494.1

McInnes RJ (2013) Towards the wise use of urban and peri-urban wetlands. Ramsar Scientific and Technical Briefing Note no. 6. Gland. Ramsar Convention Secretariat, Switzerland

MEA (Millennium Ecosystem Assessment) (2005) Ecosystems and human wellbeing: synthesis. Island Press, Washington, DC

Mitsch WJ, Gosselink JG (2000) The value of wetlands: importance of scale and landscape setting. Ecol Econ 35(1):25-33. https://doi.org/10.1016/S09218009(00)00165-8

Mitsch WJ, Gosselink JG (2015) Wetlands, 5th edn. Wiley, New Jersey

Monserud RA, Leemans R (1992) Comparing global vegetation maps with the Kappa statistic. Ecol Model 62(4):275-293. https://doi.org/10.1016/0304-3 800(92)90003-W

Msofe NK, Sheng L, Li Z, Lyimo J (2020) Impact of land use/cover change on ecosystem service values in the Kilombero Valley Floodplain, Southeastern Tanzania. Forests 11(1):109. https://doi.org/10.3390/f11010109

Paudyal K, Baral H, Bhandari SP, Bhandari A, Keenan RJ (2019) Spatial assessment of the impact of land use and land cover change on supply of ecosystem services in Phewa watershed, Nepal. Ecosyst Serv 36:100895. https://doi.org/1 0.1016/j.ecoser.2019.100895

Plummer ML (2009) Assessing benefit transfer for the valuation of ecosystem services. Front Ecol Environ 7(1):38-45. https://doi.org/10.1890/080091

Richardson L, Keefe K, Huber C, Racevskis L, Reynolds G, Thourot S, Miller I (2014) Assessing the value of the Central Everglades Planning Project (CEPP) in Everglades restoration: An ecosystem service approach. Ecol Econ 107:366377. https://doi.org/10.1016/j.ecolecon.2014.09.011

Rojas C, Munizaga J, Rojas O, Martínez C, Pino J (2019) Urban development versus wetland loss in a coastal Latin American city: Lessons for sustainable land use planning. Land Use Policy 80:47-56. https://doi.org/10.1016/j.la ndusepol.2018.09.036

Russi D, ten Brink P, Farmer A et al (2013) The economics of ecosystems and biodiversity for water and wetlands. IEEP, London and Brussels Ramsar Secretariat, Gland

Sadat M, Zoghi M, Malekmohammadi B (2019) Spatiotemporal modeling of urban land cover changes and carbon storage ecosystem services: case study in Qaem Shahr County, Iran. Environ Dev Sustain 22(8):8135-8158. https://doi.org/10.1007/s10668-019-00565-4

Seyoum S (1988) A history of Bahir Dar Town: 1936-1974. M.A. Thesis. Addis Ababa University, Addis Ababa, Ethiopia

Shewit G, Minwyelet M, Tesfaye M, Lewoye T, Ferehiwot M (2017) Land use change and its drivers in Kurt Bahir wetland, north-western Ethiopia. African J Aquat Sci 42(1):45-54. https://doi.org/10.2989/16085914.2017.1292178

Song W, Deng X, Yuan Y, Wang Z, Li Z (2015) Impacts of land-use change on valued ecosystem service in rapidly urbanized North China Plain. Ecol Model 318:245-253. https://doi.org/10.1016/j.ecolmodel.2015.01.029

Sun X, Crittenden JC, Li F, Lu Z, Dou X (2018) Urban expansion simulation and the spatio-temporal changes of ecosystem services, a case study in Atlanta Metropolitan area, USA. Sci Total Environ 622-623:974-987. https://doi.org/1 0.1016/j.scitotenv.2017.12.062

Sun X, Zhang Y, Shen Y, Randhir TO, Cao M (2019) Exploring ecosystem services and scenario simulation in the headwaters of Qiantang River watershed of 
China. Environ Sci Pollut Res 26(34):34905-34923. https://doi.org/10.1007/ s11356-019-06483-2

Teferi E, Uhlenbrook S, Bewket W, Wenninger J, Simane B (2010) The use of remote sensing to quantify wetland loss in the Choke Mountain range, Upper Blue Nile basin, Ethiopia. Hydrol Earth Syst Sci 14(12):2415-2428. https://doi.org/10.5194/hess-14-2415-2010

Temesgen H, Wu W, Shi X, Yirsaw E, Bekele B, Kindu M (2018) Variation in ecosystem service values in an agroforestry dominated landscape in Ethiopia: implications for land use and conservation policy. Sustainability 10(4):1126. https://doi.org/10.3390/su10041126

Terfa BK, Chen N, Liu D, Zhang X, Niyogi D (2019) Urban expansion in Ethiopia from 1987 to 2017: characteristics, spatial patterns, and driving forces. Sustainability 11(10):2973. https://doi.org/10.3390/su11102973

Tianhong L, Wenkai L, Zhenghan Q (2010) Variations in ecosystem service value in response to land use changes in Shenzhen. Ecol Econ 69(7):1427-1435. https://doi.org/10.1016/j.ecolecon.2008.05.018

Tolessa T, Senbeta F, Kidane M (2017) The impact of land use/land cover change on ecosystem services in the central highlands of Ethiopia. Ecosyst Serv 23: 47-54. https://doi.org/10.1016/j.ecoser.2016.11.010

Van der Ploeg S, De Groot RS, Wang Y (2010) The TEEB Valuation Database: overview of structure, data and results. In: Foundation for sustainable development, Wageningen, the Netherlands

Woldeyohannes A, Cotter M, Biru W, Kelboro G (2020) Assessing changes in ecosystem service values over 1985-2050 in response to land use and land cover dynamics in Abaya-Chamo Basin, Southern Ethiopia. Land 9(2):37. https://doi.org/10.3390/land9020037

Wondie A (2018) Ecological conditions and ecosystem services of wetlands in the Lake Tana Area, Ethiopia. Ecohydrol Hydrobiol 18(2):231-244. https://doi. org/10.1016/j.ecohyd.2018.02.002

Worku S (2018) Expansion of Khat and its impact on the farming system: the case of Bahir Dar city and Bahir Dar Zuria district. Bahir Dar University, Bahir Dar, Ethiopia

Yi H, Güneralp B, Filippi AM, Kreuter UP, Güneralp I (2017) Impacts of land change on ecosystem services in the San Antonio River Basin, Texas, from 1984 to 2010. Ecol Econ 135:125-135. https://doi.org/10.1016/j.ecolecon.2016.11.019

Yi H, Güneralp B, Kreuter UP, Güneralp I, Filippi AM (2018) Spatial and temporal changes in biodiversity and ecosystem services in the San Antonio River Basin, Texas, from 1984 to 2010. Sci Total Environ 619-620:1259-1271. https://doi.org/10.1016/.scitotenv.2017.10.302

Yirsaw E, Wu W, Shi X, Temesgen H, Bekele B (2017) Land use/land cover change modeling and the prediction of subsequent changes in ecosystem service values in a coastal area of China, the Su-Xi-Chang Region. Sustainability 9(7): 1204. https://doi.org/10.3390/su9071204

Zank B, Bagstad K, Voigt B, Villa F (2016) Modeling the effects of urban expansion on natural capital stocks and ecosystem service flows: a case study in the Puget Sound, Washington, USA. Landsc Urban Plan 149:31-42. https://doi.org/10.1016/j.landurbplan.2016.01.004

Zhang Y, Zhao L, Liu J, Liu Y, Li C (2015) The impact of land cover change on ecosystem service values in urban agglomerations along the Coast of the Bohai Rim, China. Sustainability 7(8):10365-10387. https://doi.org/10.3390/ su70810365

Zhang Z, He G, Wang X (2010) A practical DOS model-based atmospheric correction algorithm. Int J Remote Sens 31(11):2837-2852. https://doi.org/1 $0.1080 / 01431160903124682$

Zhao B, Kreuter U, Li B, Ma Z, Chen J, Nakagoshi N (2004) An ecosystem service value assessment of land-use change on Chongming Island, China. Land Use Policy 21(2):139-148. https://doi.org/10.1016/j.landusepol.2003.10.003

Zhao J, Yang Y, Zhao Q, Zhao Z (2017) Effects of ecological restoration projects on changes in land cover: a case study on the Loess Plateau in China. Sci Rep 7(1):44496. https://doi.org/10.1038/srep44496

Zorrilla-Miras P, Palomo I, Gómez-Baggethun E, Martín-López B, Lomas PL, Montes C (2014) Effects of land-use change on wetland ecosystem services: a case study in the Doñana marshes (SW Spain). Landsc Urban Plan 122:160174. https://doi.org/10.1016/j.landurbplan.2013.09.013

Wang J, Peng J, Zhao M, Liu Y, Chen Y (2017) Significant trade-off for the impact of Grain-for-Green Programme on ecosystem services in North-western Yunnan, China. Sci Total Environ 574:57-64.

\section{Publisher's Note}

Springer Nature remains neutral with regard to jurisdictional claims in published maps and institutional affiliations.

\section{Submit your manuscript to a SpringerOpen ${ }^{\circ}$ journal and benefit from:}

- Convenient online submission

- Rigorous peer review

- Open access: articles freely available online

- High visibility within the field

- Retaining the copyright to your article

Submit your next manuscript at $\boldsymbol{\nabla}$ springeropen.com 